IZA DP No. 8145

A Review of Renewable Energy Supply and Energy Efficiency Technologies

Shahrouz Abolhosseini

Almas Heshmati

Jörn Altmann

April 2014 


\title{
A Review of Renewable Energy Supply and Energy Efficiency Technologies
}

\author{
Shahrouz Abolhosseini \\ TEMEP, Seoul National University \\ Almas Heshmati \\ Sogang University, \\ Jönköping University and IZA \\ Jörn Altmann \\ TEMEP, Seoul National University
}

Discussion Paper No. 8145

April 2014

IZA

P.O. Box 7240

53072 Bonn

Germany

Phone: +49-228-3894-0

Fax: +49-228-3894-180

E-mail: iza@iza.org

Any opinions expressed here are those of the author(s) and not those of IZA. Research published in this series may include views on policy, but the institute itself takes no institutional policy positions. The IZA research network is committed to the IZA Guiding Principles of Research Integrity.

The Institute for the Study of Labor (IZA) in Bonn is a local and virtual international research center and a place of communication between science, politics and business. IZA is an independent nonprofit organization supported by Deutsche Post Foundation. The center is associated with the University of Bonn and offers a stimulating research environment through its international network, workshops and conferences, data service, project support, research visits and doctoral program. IZA engages in (i) original and internationally competitive research in all fields of labor economics, (ii) development of policy concepts, and (iii) dissemination of research results and concepts to the interested public.

IZA Discussion Papers often represent preliminary work and are circulated to encourage discussion. Citation of such a paper should account for its provisional character. A revised version may be available directly from the author. 


\title{
ABSTRACT \\ A Review of Renewable Energy Supply and Energy Efficiency Technologies
}

\begin{abstract}
Electricity consumption will comprise an increasing share of global energy demand during the next two decades. In recent years, the increasing prices of fossil fuels and concerns about the environmental consequences of greenhouse gas emissions have renewed the interest in the development of alternative energy resources. In particular, the Fukushima Daiichi accident was a turning point in the call for alternative energy sources. Renewable energy is now considered a more desirable source of fuel than nuclear power due to the absence of risk and disasters. Considering that the major component of greenhouse gases is carbon dioxide, there is a global concern about reducing carbon emissions. In this regard, different policies could be applied to reducing carbon emissions, such as enhancing renewable energy deployment and encouraging technological innovations. Two main solutions may be implemented to reduce $\mathrm{CO} 2$ emissions and overcome the problem of climate change: replacing fossil fuels with renewable energy sources as much as possible and enhancing energy efficiency. In this paper, we discuss alternative technologies for enhancing renewable energy deployment and energy use efficiency.
\end{abstract}

JEL Classification: D61, D62, H23, N50, O13, Q52, Q55

Keywords: energy resources, renewable energy, energy use efficiency, generation technology, carbon emission, green employment

Corresponding author:

Almas Heshmati

Department of Economics, Room K526,

Sogang University

35 Baekbeom-ro (Sinsu-dong \#1)

Mapo-gu, Seoul 121-742

Korea

E-mail: heshmati@sogang.ac.kr 


\section{Introduction}

Considering that the major component of greenhouse gases (GHGs) is carbon dioxide, there is a global concern about reducing carbon emissions. In this regard, different policies could be applied to reduce carbon emissions, such as enhancing renewable energy deployment and encouraging technological innovations. In addition, supporting mechanisms, such as feed-in tariffs, renewable portfolio standards and tax policies, are employed by governments to develop renewable energy generation along with implementing energy use efficiency for saving energy.

Many countries have started to install facilities that use renewable energy sources for power generation. The importance of alternative energy sources comes together with climate change challenges associated with the excessive use of fossil fuels. There are three primary motivators that stimulate the growth of renewable energy technologies: energy security, economic impacts and carbon dioxide emission reduction. The term "alternative energy" refers to any form of energy other than the conventional sources of energy, including hydropower. In recent years the focus has been on renewable energy sources.

IEA (2012d) refers to two significant global trends that should characterize the deployment of renewable technologies over the medium term. First, as renewable electricity technologies scale up, from a total global supply of 1,454 gigawatts (GW) in 2011 to 2,167 GW in 2017, they should also spread out geographically. Second, the more recent years of high fossil fuel energy use has led renewable technologies to become increasingly competitive on a cost basis with their alternatives in a number of countries and circumstances. According to IEA calculations, wind is the most competitive type of renewable energy technology among the other options, if local conditions such as financing, $\mathrm{CO}_{2}$ emission levels and fossil fuel prices prove favorable (OECD, 2010).

When talking about clean technologies, there are two primary concepts of energy technologies: energy supply technologies, which refers to alternative sources of renewable energy (e.g., wind and solar power), and energy efficiency technologies, or those technologies which are hired to enhance energy use efficiency, (e.g., combined heat and power (CHP), virtual power plants (VPP) and smart meters). It should be noted that transforming the energy sector and replacing conventional energy with renewable energy is evolutionary associated with technological change and forming markets. Jacobsson and Bergek (2004) indicate that the transforming process for certain forms of renewable energy, such as wind and solar, will happen after 2020, even if the growth rate of consumption is strongly increasing over the next decade. Also, renewable energy markets are not easily formed due to cost disadvantages and the subsidizing of fossil fuels.

The remainder of this study proceeds as follows. In Section 2 we present the different renewable energy supply technologies including solar, wind and hydro power, geothermal and other sources. In Section 3 different energy use efficiency technologies are discussed. These include electric vehicles, combined heat and power, virtual power plants and the application of smart meters. The final section provides a summary and concludes.

\section{Renewable Energy Supply Technologies}

The renewable energy supply is continuously increasing. A large amount of investment has been made during recent years and the advancement of technology has enabled countries to produce renewable energy more cost effectively. It is forecasted that the number of countries producing above 100 megawatts (MW) of renewable energy will increase significantly by 
2017 (IEA, 2012d). Due to some negative and irreversible externalities coming with conventional energy production, it is necessary to promote and develop renewable energy supply technologies. These technologies may not be comparable with conventional fuels in terms of production cost, but they could be comparable if we consider their associated externalities, such as their environmental and social effects. Also, it should be noted that economies of scale could play a key role in reducing the unit production cost. Transmission and distribution costs, as well as technologies, do not differ much among the conventional and renewable energies. Below we present facts about the development of the main renewable energy supply technologies.

\subsection{Hydro power}

Hydro power is currently the largest renewable energy source for power generation around the world. Hydro electricity generation has had a strong increase over the past 50 years. It was 340 terawatt-hour (TWh) in 1950 and covered about one-third of the global electricity demand. It increased to 1,500 TWh in 1975 and further to 2,994 in 2005. We can compare this to the global consumption of 15,000 TWh of electricity with a global production of 18,306 TWh in 2005 (Ngô and Natowitz, 2009). Currently, hydro power development is difficult due to a large initial fixed investment cost and environmental concerns. Additionally, hydro power has caused problems for local residents associated with the need to relocate large populations, as well as the construction of dams is permanent with a sunk cost of utilities which cannot be removed. The environment is also influenced by hydro power construction because of large engineering works. On the other hand, hydro power is attractive due to a preexisting supply of water for agriculture, household and industrial use, and hydro power is clean and enables the storage of both water and energy. Also, the stored energy can be used for the application of both base-load and peak time power generation.

The largest capacity hydro power plant in the world is the Itaipu Dam installed on the Paraná River and developed jointly by Brazil and Paraguay. The initial capacity was 12.6 GW in 1984, but this has since been increased to 14 GW in 2006 (Ngô and Natowitz, 2009). Many argue that hydro plant construction projects could improve local economies. For example, the US employed thousands of workers to complete the Hoover Dam project, which was constructed during the depression in 1930s (Tester, 2005). Hydro power plays a key role for some countries, such as Norway and Sweden. Based on BP statistics (2012), hydro electricity demand in Norway (122 TWh) constituted almost $64 \%$ of the primary energy consumption in 2011, compared to shares of $26 \%$ and $8 \%$ for oil and natural gas, respectively. Similarly, around $30 \%$ of energy consumption in Sweden has been supplied by hydro power (66.5 TWh). China, Brazil and Canada are the top three hydro electricity producers worldwide, with 694.0, 429.6 and 376.5 TWh generated, respectively. Figure (1) shows the general trend of worldwide hydro electricity consumption from 1965 to 2011. 


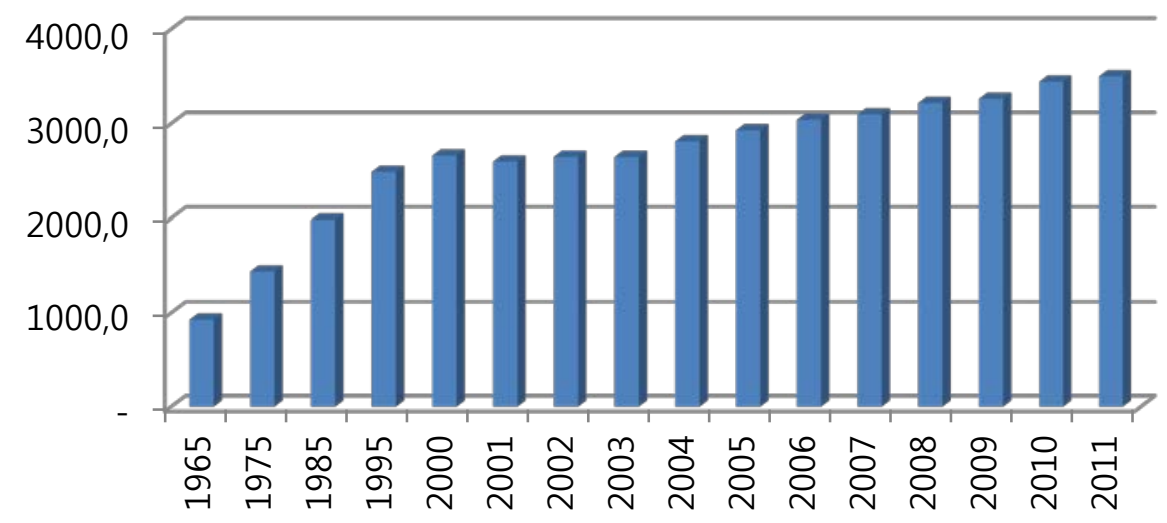

Figure (1): Worldwide hydro electricity consumption, 1965-2011 (in TWh)

The total hydropower capacity is forecasted to increase from 1,607 GW in 2011 to 1,680 GW in 2035 (IEA, 2012e). According to the World Economic Outlook (WEO) 2012 report, China is expected to double its capacity by 2035, an amount of $420 \mathrm{GW}$. To put this in perspective, $420 \mathrm{GW}$ is close to the entire capacity of OECD countries in 2011. The IEA has also estimated that the capacity will also significantly increase in India and Brazil. It is forecasted that the capacity will grow from $42 \mathrm{GW}$ to $115 \mathrm{GW}$ in India and from $89 \mathrm{GW}$ to $130 \mathrm{GW}$ in Brazil (IEA, 2012e). Other regions, such as Europe and North America where the hydropower sector has already matured, will modernize their current plants and improve storage capacity instead of developing new facilities (Martinot and Sawin, 2012). Based on the IEA survey, issues such as the availability of funding, political and market risks, and local environmental concerns are considered to be barriers to the develop of hydropower capacity in Africa. Figure (2) shows the sources of primary energy consumption on a worldwide scale for the year 2011, based on BP statistics (2012). The energy technology differs among the OECD and non-OECD countries with respect to coal, nuclear and hydro sources. The difference is attributed to their technological capabilities.

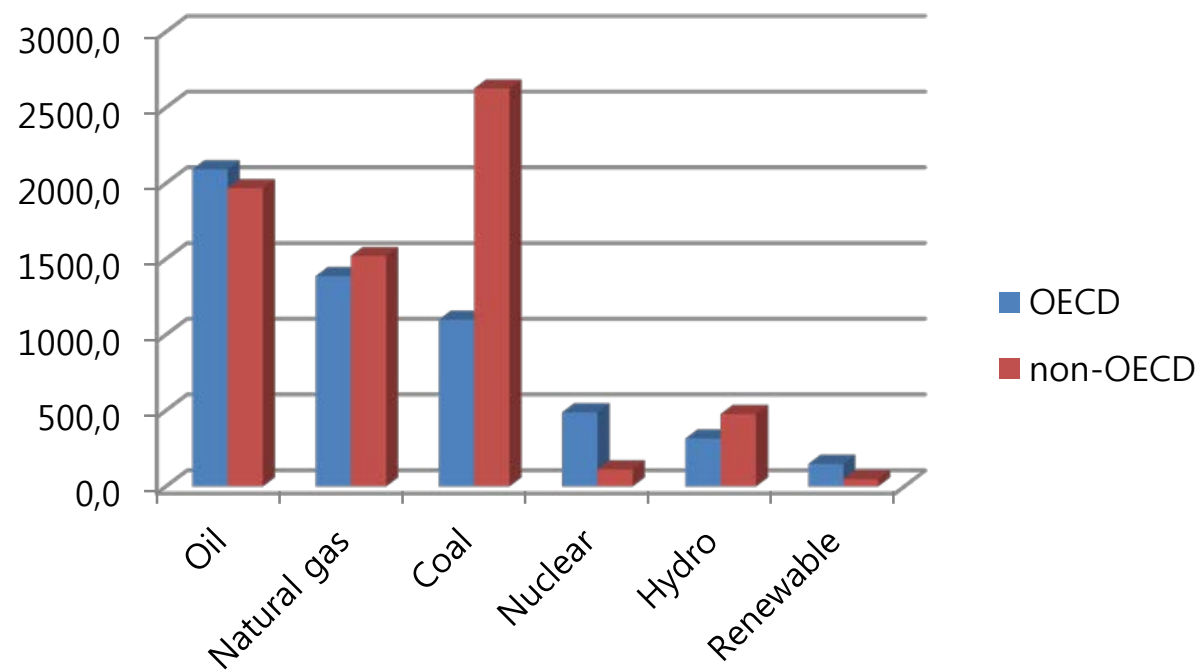

Figure (2): Primary energy consumption by source in 2011, Worldwide

There are three kinds of hydropower generation plants: (i) run-of-river, where the power is generated by the flow of a river, (ii) reservoir, where the power is generated by the release of stored water, and (iii) pumped storage, where stored water is backed up into the reservoir in 
order to be pumped again. Small scale hydropower stations are typically of the run-of-river type. Wirl (1989) examined conventional standards to evaluate hydropower plant projects and argued that the conventional cost-benefit analysis is not applicable to evaluate the expansion of plants. Wirl believed that the actual cost of hydropower plants is underestimated because of negative environmental externalities and positive dynamic spillover effects.

Sinha (1992) estimated a model for a hypothetical site to simulate performance and economic aspects of combined wind/hydro/diesel power plants with pumped storage. His model constitutes a wind energy conversion system, a mini/micro hydro plant, a diesel generator and a pump. The results show that pumped storage doesn't have a significant effect when wind and water systems are applied. However, it could be used in sites without natural inflows. Gagnon (1997) discussed GHG emissions from hydropower plants and shows that hydropower is a good alternative compared to fossil fuel power plants in most cases. Based on the results, a typical GHG emission factor is $15 \mathrm{~g} \mathrm{CO}_{2}$ equivalent/kWh, an amount which is 30-60 times less than conventional fossil fuel power plants. Paish (2002) argued that the main advantages for small-scale hydropower include a more concentrated energy resource than wind or solar, predictability, on demand availability, limited maintenance, long-lasting technology, lack of fuel, and no environmental impact. Paish as additionally recognizes shortcomings including site-specific technology, the limitation of expansion activities, a monsoon condition, conflicts with fisheries, and a lack of knowledge in the ability to apply this technology in many areas.

Lehner et al. (2005) applied a model to analyze possible impacts of climate change on Europe's hydropower potential at the country level. They analyzed both the gross hydropower potential and the developed potential of current plants in order to capture a realistic picture of present and future power generation. The results strongly indicated that the hydropower potential in Europe is influenced by climate change, with a possible reduction of $25 \%$ or more for southern and southeastern European countries. It is estimated that gross hydropower potential for Europe will decrease about $6 \%$ by the 2070s, while the reduction rate for developed hydropower potential will be $7-12 \%$. It has been acknowledged that significant adoption is required for water management in the future in Europe. Ehnberg and Bollen (2005) investigated the availability of hybrid power plants using a model simulated for the following power combinations: (i) solar power, (ii) solar power and storage, (iii) solar and hydro power, and (iv) solar and hydro power with storage. The results indicate that a combination of different sources should be employed in order to have a reliable supply. A combination of solar power with a small reservoir is found to be favorable over other options.

Kaldellis et al. (2010) introduced a methodology to measure the size of pumped hydro storage (PHS) systems to take advantage of excess wind energy generated by local wind farms, but that are rejected by local power grids due to electrical limitations. Their finding shows that the ability of PHS systems has significant contributions in the electrification of remote islands. They surmised that this methodology could be developed and applied to all hybrid projects that constitute a combination of wind farms, pumped storage and hydroturbines. Kapsali and Kaldellis (2010) investigated the feasibility of a wind-based PHS system that would be able to supply local power to an Aegean Sea island, where PHS systems located at isolated sites are able to use rejected wind energy produced by wind farms. Based on the results, the project is viable from a technical and economical point of view. The evidence indicates that a PHS project could be considered more environmental friendly than conventional plants because it would take required energy during low demand periods from a local grid when the thermal unit operation generates less gas emissions. 
Deane et al. (2010) reviewed current and planned pumped hydro energy storage (PHES), as well as analyzed technical and economical drivers for developing PHES. Based on the results, current trends for developing PHES show an intention to enhance or build pump back plants instead of pure pumped storage. Capital costs for proposed projects in the reviewed sites are estimated at 470-2,170 Euro/kWh. It is stated that developers of new PHES, particularly in Europe, intend to have hybrid wind-hydro power plants. Raadal et al. (2011) reviewed life cycle GHG emissions from wind and hydro electricity production and compared them to other types of energy sources. Based on the results, GHG emissions produced by the run-ofriver hydro plant life cycle analysis shows the lowest variation among the examined technologies.

Yang and Jackson (2011) investigated the historical development of PHES in United States and analyzed case studies, disputed projects and challenges about future development of these projects in United States. Their findings show that interest in PHES systems has increased worldwide in recent years, with an expectation that a capacity of $76 \mathrm{GW}$ will be installed by 2014. There are 32 preliminary permits granted to 25 licensees in the United States to develop new PHES facilities. Yang and Jackson pointed out that PHES development may be influenced by an increased supply of unconventional natural gas, making it noncompetitive for use during peak times for an electricity network. But, they argued that the possibility of new laws on price and/or restrictions on carbon emission could stimulate the economic outlook of PHES.

Connolly et al. (2011) applied a deterministic model to compare three operation strategies for optimizing profit in a PHES facility utilizing price arbitrage on 13 electricity spot markets. They found that an optimal strategy is achieved based on day-ahead electricity prices and that $97 \%$ of profits could be earned by using this strategy. It is indicated that a long-term forecast is not required in order to maximize profit using electricity price arbitrage. Monteiro et al. (2013) estimated a short-term forecasting model for hourly average power generation of small-hydro power plants (SHPPs). Their model comprises three modules: estimation of the daily average, final forecasts of hourly average power generation and dynamic adjustment by recent historical data. They argued that the model provides practical solutions for technical and economic problems made by SHPPs. The authors concluded that power generation forecasts are required in order to operate SHPPs appropriately for preparing bid offers in the markets and maintenance schedules of power plants.

Table (1): Empirical research about power generation by hydro power technology

\begin{tabular}{|l|l|l|}
\hline Authors & Subject & Result \\
\hline Sinha (1992) & $\begin{array}{l}\text { Modeling the economics of } \\
\text { combined power systems }\end{array}$ & $\begin{array}{l}\text { Pumped storage doesn't have a significant effect } \\
\text { when wind and water systems are applied. But, it } \\
\text { could be used for sites without natural inflows. }\end{array}$ \\
\hline Gagnon (1997) & $\begin{array}{l}\text { GHG emissions from } \\
\text { hydropower }\end{array}$ & $\begin{array}{l}\text { A typical GHG emission factor is 15g CO } \text { CO }_{2} \\
\text { equivalent/kWh, 30-60 times less than fossil fuel } \\
\text { generation. }\end{array}$ \\
\hline Paish (2002) & $\begin{array}{l}\text { Small hydropower } \\
\text { technology }\end{array}$ & $\begin{array}{l}\text { Main advantage: more concentrated energy, } \\
\text { predictability, on demand availability, limited } \\
\text { maintenance, long-lasting technology, no fuel. }\end{array}$ \\
\hline $\begin{array}{l}\text { Lehner et al. } \\
\text { (2005) }\end{array}$ & $\begin{array}{l}\text { Impact of climate change } \\
\text { on hydropower in Europe }\end{array}$ & $\begin{array}{l}\text { Climate change fosters a reduction of 25\% or } \\
\text { more in the hydropower potential for southern and } \\
\text { southeastern Europe. }\end{array}$ \\
\hline Ehnberg and & Reliability of a small power & A combination of different sources should be \\
\hline
\end{tabular}




\begin{tabular}{|l|l|l|}
\hline Authors & Subject & Result \\
\hline Bollen (2005) & system with solar and hydro & $\begin{array}{l}\text { hired to have reliability. Combination of solar } \\
\text { power and small reservoir is more favorable. }\end{array}$ \\
\hline $\begin{array}{l}\text { Kaldellis et al. } \\
(2010)\end{array}$ & $\begin{array}{l}\text { Analysis of wind-based } \\
\text { pumped hydro energy } \\
\text { storage (PHES) }\end{array}$ & $\begin{array}{l}\text { The ability of PHES has a significant contribution } \\
\text { in the electrification of remote islands. }\end{array}$ \\
\hline $\begin{array}{l}\text { Kapsali and } \\
\text { Kaldellis } \\
(2010)\end{array}$ & $\begin{array}{l}\text { Combining hydro and } \\
\text { variable wind power } \\
\text { generation }\end{array}$ & $\begin{array}{l}\text { PHS systems are viable from a technical and } \\
\text { economical point of view at isolated sites. }\end{array}$ \\
\hline $\begin{array}{l}\text { Deane et al. } \\
(2010)\end{array}$ & $\begin{array}{l}\text { Techno-economics review } \\
\text { of pumped hydro energy } \\
\text { storage }\end{array}$ & $\begin{array}{l}\text { Capital cost for PHES is estimated to be 470- } \\
\text { 2,170 Euro/kWh. It is intended to have hybrid } \\
\text { wind-hydro power plants in Europe. }\end{array}$ \\
\hline $\begin{array}{l}\text { Raadal et al. } \\
(2011)\end{array}$ & $\begin{array}{l}\text { Life cycle GHG emission } \\
\text { from the generation of wind } \\
\text { and hydro power }\end{array}$ & $\begin{array}{l}\text { GHG emissions from wind and hydro power } \\
\text { varies from 0.2 to 152g CO2-equivalents per kWh. } \\
\text { Run-of-river hydro plant have the lowest. }\end{array}$ \\
\hline $\begin{array}{l}\text { Yang and } \\
\text { Jackson (2011) }\end{array}$ & $\begin{array}{l}\text { Opportunities and barriers } \\
\text { to PHES in the US }\end{array}$ & $\begin{array}{l}\text { PHES may be negatively influenced by } \\
\text { developing natural gas. New price and emission } \\
\text { laws can stimulate its outlook. }\end{array}$ \\
\hline $\begin{array}{l}\text { Monteiro et al. } \\
\text { (2013) }\end{array}$ & $\begin{array}{l}\text { Forecasting model for } \\
\text { power production of small- } \\
\text { hydro }\end{array}$ & $\begin{array}{l}\text { Power generation forecasts are required to operate } \\
\text { small hydro power plants appropriately for } \\
\text { preparing bid offers and a maintenance schedule. }\end{array}$ \\
\hline
\end{tabular}

\subsection{Wind power}

The installed capacity of wind power has increased from 4.8 MW in 1995 to more than 239 GW in 2011. Today, each wind turbine could generate as much electricity as a conventional power plant. Wind energy has made its most significant contributions in China, the US and Germany, where the cumulative installed capacities are 62, 47 and 29 GW, respectively. Figure (3) shows the worldwide wind installation capacity trend based on the BP (2012) report.

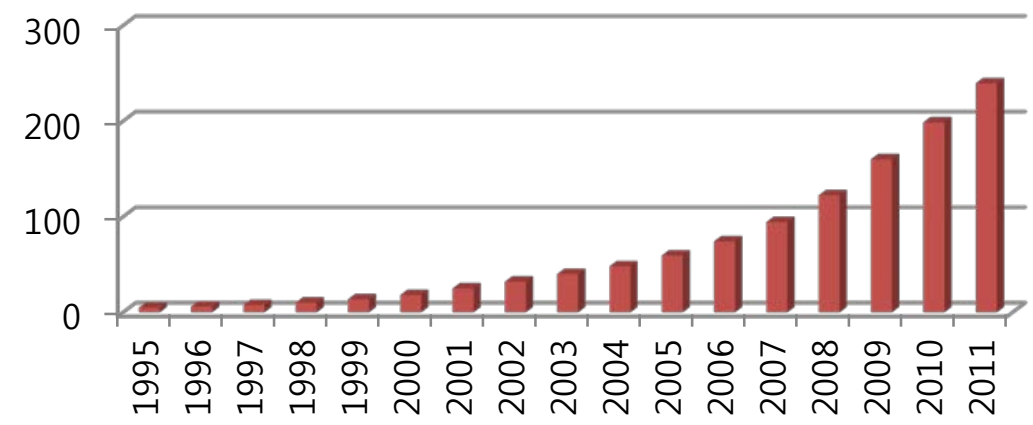

Figure (3): Cumulative installed wind turbine capacity, 1995-2011 (in GW)

The trend shows that wind capacity installation has increased continuously throughout the last two decades. IEA estimates that the global capacity will increase from $238 \mathrm{GW}$ in 2011 to almost $1,100 \mathrm{GW}$ by 2035 , of which $80 \%$ will be derived from onshore wind turbines (IEA, 2012e). According to this report, offshore wind capacity is expected to grow fairly quickly from $4 \mathrm{GW}$ in 2011 to $175 \mathrm{GW}$ by 2035 as a result of public support. This target will be achieved if the required investment is made based on the design plan. Estimates indicate that around 980 billion USD is required in investments between 2010-2020, with increases to 
1,634 and 3,307 billion USD for 2020-2030 and 2030-2050, respectively (IEA, 2012e). Figure (4) shows the breakdown of investment needs. The figure shows that the investment of OECD countries will fall behind non-OECD countries by 2030-50. The main portion of investment from the non-OECD group (almost 50\%) belongs to China.

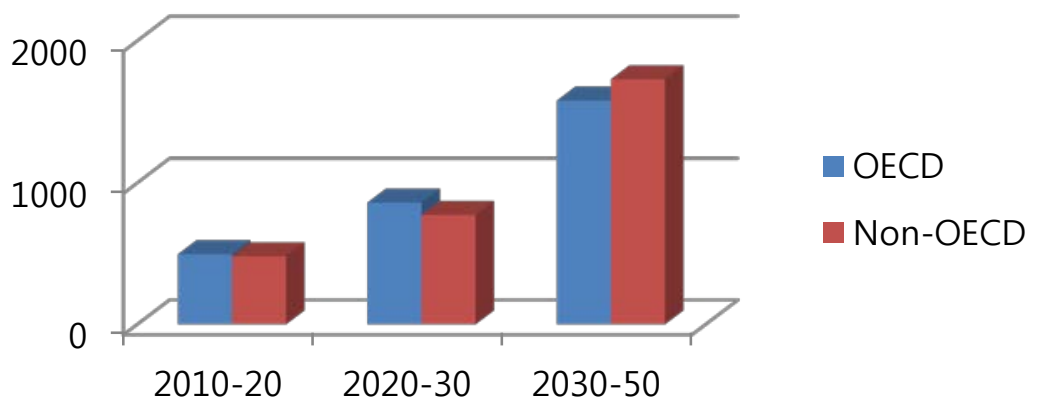

Figure (4): Investments to achieve wind generation targets, 2010-2050 (billions USD)

Tester (2005) mentioned that each renewable energy type comes from one of three primary energy sources: solar radiation, gravitational forces and heat generated by radioactive decay. Tester argued that solar, thermal and photovoltaic energy are produced by capturing a fraction of incident solar. Wind, hydro, wave, ocean thermal, and biomass energy are also indirectly produced by solar. According to Tester, this competency could improve in the long-term. Tester estimated the lifetime-leveled cost for wind power to equal 6.5 cents per kilowatt hour, comparable to natural-gas combined cycle gas turbines (CCGT) and coal power plants if externality costs are considered. Furthermore, the author acknowledges additional advantages of wind power plants, including the installation as turnkey contracts within a short period, lower investment costs compared to nuclear and hydroelectric plants, economies of mass production, an absence of fuel costs and improvement in the operating and maintenance costs.

Based on Ngô and Natowitz (2009), the problems associated with the use of wind energy sources include the intermittency of wind energy and an added cost for power transmission to residential areas. Since wind turbines are installed on windy sites where the population density tends to be lower, offshore wind turbines are considered a viable alternative for landbased turbines, especially in areas with limited land resources or where there is opposition from local residents. The largest offshore wind farm, located in Denmark, includes 80 turbines that produce $2 \mathrm{MW}$ of power. According to Ngô and Natowitz, Denmark exports the majority of power it generates from wind turbines, because the domestic demand is substantially less than the power produced.

Gipe (1995) argued there are crucial limitations to the successful use of wind energy. From a financial sense, these factors include the costs, revenues, and expected returns on investment. Financial targets could be managed by taxes, but other factors such as national energy policy may be important. Costs include both installation and operation expenditures, where revenue is dependent on wind resources, a turbine's performance and the quantity of energy produced. For a wind plant, this value is defined by the purchase power rate or a feed-in tariff. This value is calculated based on the price paid to the utility plus the transmission cost to their house, where the price of wind energy depends on how much energy is demanded by local residents. Therefore, the feasibility and minimum required speed for a wind turbine to be economically viable is related to how much wind energy is worth.

Gipe (1995) conducted two case studies in Europe and Great Britain. This study found that wind energy is highly valued in northern Europe with 5.0-6.5 m/s a sufficient wind speed to 
constitute a feasible energy source, but that the average speed in Great Britain should exceed $7.0 \mathrm{~m} / \mathrm{s}$ due to an associated tariff risk. Gipe argued that wind turbines could be successful when there is a market for generated power, in which some households sell a part of their wind turbines' excess power generation back to a local utility. An agreement is required between parties to process this transaction, and at this step, feasibility depends on government policy for pricing. Pricing policies have been different in United States and Denmark, which has subsequently affected the installed capacity.

Devine (1977) used an input-output approach to calculate energy production from a 1,500 $\mathrm{kW}(\mathrm{e})$ wind turbine used to displace fossil fuel in a power system. Comparing five ratios for delivered electricity, he found that this system was able to displace a portion of the fossil fuel equivalent. Haack (1981) calculated the net energy of a small wind conversion system in the US and compared it to other fossil fuel based electricity generation sources. He estimated the energy production through a simulation model taking into account wind speeds, residential electricity demands and parameters from the generator, inverter and storage components. The results showed that net energy obtained by the wind system is better than other systems. Haack argued that additional steps used in the process of obtaining fuels by new technologies increase the efficiency of conversion.

Schleisner (2000) examined energy consumption and emission generated through the production and manufacturing of materials for onshore and offshore wind farms based on a life cycle analysis (LCA) model in Denmark. He calculated the weight of materials and energy requirements for the production, manufacturing and disposal processes. Additionally, he compared the primary energy used in production to the disposal of materials in order to calculate the energy payback time. Based on his research, the energy payback time would be 0.39 years, or less than $2 \%$ of a 20 -year life span, using an estimation of $40 \%$ for energy efficiency. He estimated that the unit external cost (mECU) of $\mathrm{CO}_{2}$ emissions for wind farms on land and offshore to be 0.8-1.2 mECU/kWh and 1.0-1.6 mECU/kWh, respectively. To put this in perspective, the external cost for a nuclear power plant in Germany has been estimated at 4.4-7.0 $\mathrm{mECU} / \mathrm{kW}$ (Bodansky, 2005).

Lenzen and Munksgaard (2002) conducted an analysis of energy use and $\mathrm{CO}_{2}$ emission reduction over the life cycle of wind turbines. They found that small wind turbines, those producing $1 \mathrm{~kW}$, require a considerably higher amount of energy over their life cycle compared to ones of a larger size, due to the price of energy required for the materials. Based on their research, it is suggested that to minimize the uncertainties in the life cycle assessment, one should use a standardized methodology and input-output based hybrid techniques. Liberman (2003) employed Monte Carlo simulation methods to analyze the economic return and life cycle assessment of wind turbines in United States at 239 locations. The result shows that wind turbines are not feasible at all locations, but they could be superior to generators using natural gas or coal at locations with more favorable wind sources.

Korpaas et al. (2003) used an algorithm to analyze the optimal energy exchange together with energy storage in the market for a certain period. Transmission constraints and the intermittence character of wind energy have been taken into account in this research. The result shows that energy storage enables wind power plants' owners to take advantage of spot markets. Lenzen and Wachsmann (2004) conducted a life-cycle assessment to compare energy and $\mathrm{CO}_{2}$ embodied in a particular wind turbine (E-40) with a nominal power of 500 or $600 \mathrm{~kW}$ and manufactured in Germany and Brazil. A comparison shows that the $\mathrm{CO}_{2}$ balance is much lower in Brazil than in Germany, due to natural gas and nuclear power plants playing a key role in Germany but firewood and sugar-cane-based alcohol being used exclusively in 
Brazil. They investigated five scenarios of production and operation of this wind turbine in these countries and found that $\mathrm{CO}_{2}$ emissions are considerably lower if the turbine is manufactured in Brazil.

Wagner and Pick (2004) calculated an energy yield ratio and a cumulative energy demand for two types of wind turbines (1.5 and 0.5 MW) at three different site locations: (i) coastal, (ii) near the coast, and (ii) inland. Based on the results, the energy payback time would be 3-7 months with an energy yield ratio of 38-70, depends on the type of turbine and site. They also found that the deviation of the energy yield ration for different types to only be $10 \%$. Klaassen et al. (2005) used a learning curve to examine how cost reducing innovation is influenced by public R\&D support for wind farms in Denmark, Germany and UK. Based on the results, they estimated a rate of $5.4 \%$ for learning-by-doing and $12.6 \%$ for learning-byresearch.

Benitez et al. (2008) used a nonlinear optimization program by load data for Alberta, Canada's grid to examine the economic and environmental effects of wind energy penetration in a power network. Based on their calculations, the generation cost of wind energy turbines is estimated at 37-68 USD/MWh, with the reduction cost of $\mathrm{CO}_{2}$ emissions being 41-56 USD/tone. The results show that hydropower could offset most of the peak load demand, as well as eliminate building gas-fired generators for peak times. Tremeac (2009) and Tremeac and Meunier (2009) used life cycle assessment to examine environmental impacts of $4.5 \mathrm{MW}$ and $250 \mathrm{MW}$ wind turbines and considered all steps in their analysis. They found that wind energy could be the best environmental solution if three conditions are met: first, use high efficient turbines on a proper site in view of a wind source; second, consume less energy in the transportation step; and third, perform the recycling process correctly.

Blanco (2009) investigated recent studies about wind energy manufacturers in order to categorize generation costs for onshore and offshore turbines. Also, she analyzed the supply chain constraint and found that the main factors that made costs increase by $20 \%$ during the last three year were raw materials and an increased demand for wind turbines. Based on this result, the generation cost is estimated at 4.5-8.7 Eurocents/kWh for onshore and 6.0-11.1 Eurocents/kWh for offshore wind turbines. Blanco believed that a long term policy framework is required to decrease the generation cost of wind energy in the long term. She argued these policies could focus on R\&D in the optimization of the size of a turbine and new materials for blades, remote-control devices for operation and management, advanced forecasting techniques, and availability of funds.

Crawford (2009) used a hybrid embodied energy analysis approach to assess life cycle energy and GHG emissions for $850 \mathrm{~kW}$ and 3.0 MW wind turbines. Additionally he examined the impact of turbine size on the energy yield ratio. He argued that the methodologies used in previous research regarding life cycle energy studies are incomplete due to limitations and errors in the quantification of key parameters. Based on the results, energy yield ratios of 21 and 23 are estimated for small and large scale wind turbines. Crawford found that the size of wind turbine is not an important parameter in the optimization of life cycle energy performance. Kubiszewski et al. (2010) reviewed the literature on the net energy return for wind turbines' power published during 1977-2007. The results show that the average energy return on investment (EROI) for all studies, including both operational and conceptual, is 25.2, while it is only 19.2 for operational studies. This places wind in a good position compared to fossil fuels, nuclear power and solar power generation.

Sundararagavan and Baker (2012) applied cost analyses for different types of energy storage technologies, which are useful for mitigating the uncertainty of integrating wind turbines and 
power grids due to the intermittency of wind power. They argued there are three key factors required for this integration: (i) load shifting, (ii) frequency support at the transmission and distribution levels, and (iii) power quality to smooth power fluctuations. The results show that no single technology could dominate all three applications. The assumptions about interest rates and the perspective of decision makers play a crucial role to technology selection.

Table (2): Empirical research about power generated by wind power technology

\begin{tabular}{|c|c|c|}
\hline Authors & Subject & Result \\
\hline Haack (1981) & $\begin{array}{l}\text { Net energy analysis of small } \\
\text { wind energy conversion } \\
\text { systems }\end{array}$ & $\begin{array}{l}\text { Small wind electric system are energetically } \\
\text { competitive and at an advantage over other } \\
\text { electricity generating systems. }\end{array}$ \\
\hline $\begin{array}{l}\text { Schleisner } \\
(2000)\end{array}$ & $\begin{array}{l}\text { Life cycle assessment of a } \\
\text { wind farm and its } \\
\text { externalities }\end{array}$ & $\begin{array}{l}\text { Energy payback time (EPBT) would be } 0.39 \\
\text { years, or less than } 2 \% \text { of a } 20 \text {-years life span, if } \\
40 \% \text { energy efficiency is assumed. }\end{array}$ \\
\hline $\begin{array}{l}\text { Lenzen and } \\
\text { Munksgaard } \\
\text { (2002) }\end{array}$ & $\begin{array}{l}\text { Review of energy and } \mathrm{CO}_{2} \\
\text { life cycle analyses of wind } \\
\text { turbines }\end{array}$ & $\begin{array}{l}\text { It is suggested uncertainties can be minimized by } \\
\text { using a standardized methodology and input- } \\
\text { output based hybrid techniques. }\end{array}$ \\
\hline $\begin{array}{l}\text { Liberman } \\
(2003)\end{array}$ & $\begin{array}{l}\text { Economic payback and life } \\
\text { cycle assessment of utility- } \\
\text { scale wind turbines in the } \\
\text { US }\end{array}$ & $\begin{array}{l}\text { Wind turbines are not feasible at all locations, but } \\
\text { they could be superior to generators using natural } \\
\text { gas or coal at proper locations. }\end{array}$ \\
\hline $\begin{array}{l}\text { Korpaas et al. } \\
(2003)\end{array}$ & $\begin{array}{l}\text { Operation and sizing of } \\
\text { energy storage for wind } \\
\text { power plants }\end{array}$ & $\begin{array}{l}\text { Energy storage enables wind power plants' } \\
\text { owners to take advantage of spot markets. These } \\
\text { devices are an expensive but feasible option for } \\
\text { some places. }\end{array}$ \\
\hline $\begin{array}{l}\text { Lenzen and } \\
\text { Wachsmann } \\
\text { (2004) }\end{array}$ & $\begin{array}{l}\text { Geographical variability in } \\
\text { life-cycle assessment }\end{array}$ & $\begin{array}{l}\text { A production shift abroad could be a good } \\
\text { solution in order to achieve emission reduction. }\end{array}$ \\
\hline $\begin{array}{l}\text { Wagner and } \\
\text { Pick (2004) }\end{array}$ & $\begin{array}{l}\text { Energy yield ration for wind } \\
\text { energy converters }\end{array}$ & $\begin{array}{l}\text { Energy payback time (EPBT) would be } 3-7 \\
\text { months and energy yield ratio is 38-70 (depends } \\
\text { on type and site). }\end{array}$ \\
\hline $\begin{array}{l}\text { Klaassen et al. } \\
\text { (2005) }\end{array}$ & $\begin{array}{l}\text { The impact of R\&D on wind } \\
\text { energy innovation in } \\
\text { Denmark, Germany, UK }\end{array}$ & $\begin{array}{l}\text { A rate of } 5.4 \% \text { is estimated for learning-by-doing } \\
\text { and } 12.6 \% \text { for learning-by-research to develop } \\
\text { wind farms. }\end{array}$ \\
\hline $\begin{array}{l}\text { Benitez et al. } \\
\text { (2008) }\end{array}$ & $\begin{array}{l}\text { The economics of wind } \\
\text { power with energy storage } \\
\text { for Alberta, Canada }\end{array}$ & $\begin{array}{l}\text { Generation cost of wind energy turbines is } \\
\text { estimated at 37-68 USD/MWh and reduction cost } \\
\text { of } \mathrm{CO}_{2} \text { emissions would be } 41-56 \text { USD/tone. }\end{array}$ \\
\hline Meunier (2009) & $\begin{array}{l}\text { Life cycle analysis of } 4.5 \\
\text { MW and } 250 \text { MW wind } \\
\text { turbines }\end{array}$ & $\begin{array}{l}\text { Wind energy could be the best environmental } \\
\text { solution to mitigate climate change and supply } \\
\text { electricity in off-grid areas. }\end{array}$ \\
\hline Blanco (2009) & $\begin{array}{l}\text { The economics of wind } \\
\text { energy }\end{array}$ & $\begin{array}{l}\text { Generation cost is estimated to be } 4.5-8.7 \\
\text { Eurocents/kWh for onshore and } 6.0-11.1 \\
\text { Eurocents/kWh for offshore wind turbines. }\end{array}$ \\
\hline $\begin{array}{l}\text { Crawford } \\
(2009)\end{array}$ & $\begin{array}{l}\text { Life cycle analysis and GHG } \\
\text { emission analysis for wind } \\
\text { turbine }\end{array}$ & $\begin{array}{l}\text { The size of a wind turbine is not an important } \\
\text { parameter to optimize life cycle energy } \\
\text { performance. }\end{array}$ \\
\hline $\begin{array}{l}\text { Kubiszewski et } \\
\text { al. (2010) }\end{array}$ & $\begin{array}{l}\text { Net energy return for wind } \\
\text { power systems }\end{array}$ & $\begin{array}{l}\text { Average energy return on investment (EROI) for } \\
\text { all studies, including operational and conceptual, } \\
\text { is } 25.2 \text {, while it is } 19.2 \text { for operational studies. }\end{array}$ \\
\hline $\begin{array}{l}\text { Sundararagava } \\
\mathrm{n} \text { and Baker }\end{array}$ & $\begin{array}{l}\text { Evaluating energy storage } \\
\text { technologies for wind power }\end{array}$ & $\begin{array}{l}\text { Assumptions about interest rates play a crucial } \\
\text { role in the selection of technologies which in turn }\end{array}$ \\
\hline
\end{tabular}




\begin{tabular}{|l|l|l|}
\hline Authors & Subject & Result \\
\hline$(2012)$ & & depend on the perspectives of decision makers. \\
\hline
\end{tabular}

\subsection{Solar power}

During the two last decades, the economic feasibility of solar power for residential, commercial and industrial consumption has been investigated by researchers. Industrial countries like Japan and Germany are looking for alternative sources of energy such as solar power due to the limited availability of natural primary energy sources. In early 1990s, Japan started to take advantage of large-scale electricity generation by solar photovoltaic (PV), and was soon followed by Germany. Currently, both countries have taken the lead in the manufacture and production of solar power technologies. More recently, China has developed an extensive solar power capacity due to cheap labor and government subsidies, in turn, decreasing the cost of solar power generation.

Alongside the cost reduction in power generated through conventional solar PV technologies, the advancement, and increase in efficiency, of concentrated solar power technologies in the US has further reduced the cost of electricity in the solar power industry (Gevorkian, 2012). On the other hand, there are also negative effects caused by solar technologies, such as impacts on buildings' aesthetics, routine and accidental releases of chemicals, land use, etc. (Tsoutsos et al., 2005). The solar photovoltaic market has experienced extraordinary growth over the last five years. The market has increased from 9,564 MW in 2007 to 69,371 MW in 2011. Figure 3.5 shows the trend since 1996 to 2011 based on the BP (2012) report.

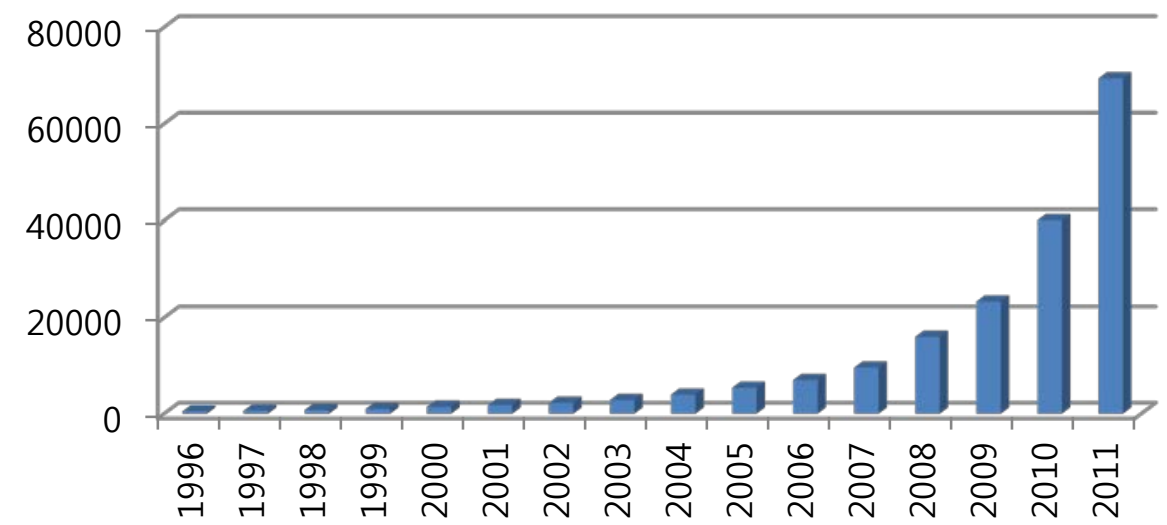

Figure (5): Cumulative installed solar PV capacity, 1996-2011 (in MW)

Almost $30 \mathrm{GW}$ of new capacity was installed worldwide in 2011, leading to an increase in the total world capacity to $69 \mathrm{GW}$. A major part of this new capacity has been due to tariff support policies, the expiration date of some policies and price reductions, all towards the end of the year. Turkey increased its capacity by 1,353\% in 2011from 2010. Bulgaria, Italy, Slovakia, and Greece have also increased their capacity over the same time. It is expected that there will be a movement to establish PV production on a mass scale between 2010 and 2020, followed by the integration of PV systems into the power grid thereafter. Figure 3.6 shows the investment needs to install solar PV systems by 2050 (IEA, 2012c) 


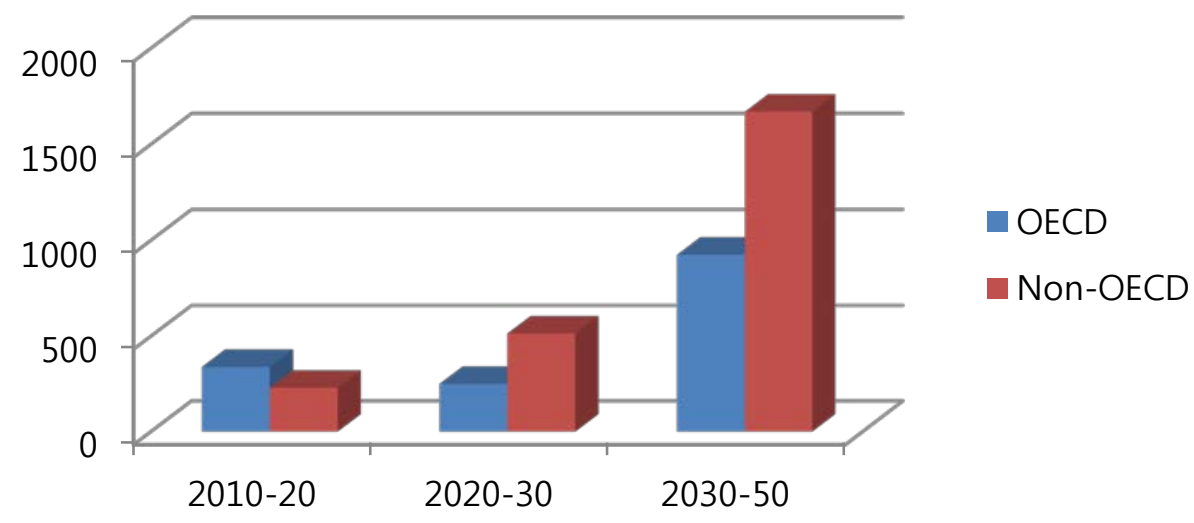

Figure (6): Investment to achieve solar PV power generation target, 2010-2050 (billions USD)

Similar to wind energy, solar energy is dependent on weather conditions. Variation in weather, including clouds and pollution, could affect solar power generation. There is a major difference between wind and solar power, as solar power has time limitations. Therefore, solar power generation varies by season, location and daytime. Many technologies are used to deploy solar radiation including thermal solar energy, concentrated solar power plants (CSP), solar chimneys or towers and photovoltaic systems (Ngô and Natowitz, 2009). Photovoltaic technology allows the integration of PV collectors into the building and can turn external walls, windows and roofs into PV collectors. However, some environmental and health concerns can arise from the use of materials in the PV systems (Tester, 2005). Sarver et al. (2013) examined and summarized the research on challenges, such as dust problems, for solar panels.

Gordon (1987) analyzed the optimal sizing of stand-alone photovoltaic power generation systems in order to design a cost effective alternative for conventional fossil fuel generators in developing countries, where most people live in rural and off-grid areas. Frankl et al. (1997) evaluated the benefits of building-integrated PV systems, comparing them to conventional PV power plants through the aspects of a life cycle analysis, maximizing energy efficiency and $\mathrm{CO}_{2}$ reduction potential. The results show favorable effects for building-integrated PV systems in terms of the energy production and reduction in $\mathrm{CO}_{2}$ emissions. They estimated $\mathrm{CO}_{2}$ yields of 2.6 and 5.4 for conventional PV power plants and building-integrated systems, respectively. These benefits are estimated to increase in the future with the advancement of PV technologies.

Market interests to expand renewable energy use, including solar power, has increased globally. Oliver and Jackson (1999) proposed certain markets as the main markets for solar PVs. They proposed that satellites, remote industries, remote communities, solar home systems, and remote houses could be considered niche markets for solar PV power. Nieuwenhout (2001) investigated experimental evidence for solar home systems (SHS) in developing countries and found that an adequate level of service infrastructure is required for the viability of solar PV projects. A number of potential problems were identified. Kolhe et al. (2002) analyzed the economic feasibility of a stand-alone solar photovoltaic (SAPV) system, comparing it to diesel power plants, in India. The results show that PV systems have the lowest cost up to $15 \mathrm{kWh}$ of energy use, but that it could be increased to $68 \mathrm{kWh} /$ day under more favorable economic conditions. The break-even point increases if the cost of PVs decrease and diesel costs increase.

Waldau (2006) examined the European photovoltaic market and observed a growth rate of $40 \%$ 
during a five year period, making photovoltaic production one of the fastest growing industries. He argued this industry needs a reliable political framework to ensure returns on investment, as well as continuous research to find cost effective material, device designing, and ways to increase efficiency. Nawaz and Tiwari (2006) analyzed energy payback time and $\mathrm{CO}_{2}$ emissions of PV systems in India. It is estimated that the energy payback time (EPBT) is in the range of 7-26 years and that $\mathrm{CO}_{2}$ emissions reduction with existing technology to be in the range of $18-160 \mathrm{~kg} / \mathrm{m}^{2} /$ year.

Shum and Watanabe (2007) compared the roll-out of PV technologies in Japan and the US and applied two models, manufactured technology and information technology, to explain the differences in technology strategies. Ito et al. (2008) examined five types of $100 \mathrm{MW}$ (very large-scale) photovoltaic power (VLS-PV) generators in the Gobi Desert (China), from the economic and environmental points of view. The results show that the energy payback time is between 1.5-2.5 years and the $\mathrm{CO}_{2}$ emission rate is between $9-16 \mathrm{~g} / \mathrm{kWh}$. Also, the generation cost was estimated to be 11-12 US Cents/kWh for using 2 USD/W PV modules, and 19-20 US Cents/kWh for using 4 USD/W PV modules.

Fthenakis and Kim (2007) considered the entire life cycle of energy use for solar and nuclear power generation and compared their potential for GHG emission reductions in the US. They used data from 12 photovoltaic companies and reviewed their nuclear-fuel life cycles in the US, Europe, and Japan. The results show that GHG emissions (based on $\mathrm{CO}_{2}$ equivalent) are 22-49 g/kWh (average US) and 17-39 g/kWh (southwest) for solar energy and 16-55 g/kWh for nuclear power. In another study Fthenakis et al. (2008) analyzed the life cycle of GHG, criteria pollutants, and heavy metal emissions for four types of PV technologies. They found that thin-film cadmium telluride has the least amount of emissions. The differences in emissions for various PV technologies are too small for comparison with conventional energy which is supposed to be replaced with PV systems. Feltrin and Freundlich (2008) examined different solar PV technologies based on globally available material reserves for large scale power generation. Results show that both improvement and innovation are required to overcome the material challenge.

Raugei and Frankl (2009) proposed three alternative scenarios for the future development of PV systems from the current time to year 2050, and they argued that these scenarios are likely to play an important role in the future energy mix. Fthenakis et al. (2009) used hourly load data for the entire US, as well as 45-years of solar irradiation data, and proposed a plan based on PV and CSP technologies. They believed that solar energy has so far been a minor contributor due to the cost and intermittency factor of solar energy, but that cost reductions made by new emerging technologies can enable solar power to be compatible with fossil fuels. They show that solar power has the capability to supply $69 \%$ of the total electricity demand and $35 \%$ of the total energy demand in the US, all by the year 2050. Based on their research, it could increase to $90 \%$ when extended to the year 2100 .

In a recent study, Huo et al. (2011) applied the Granger causality relationship between PV market sales and manufacturing development in the US, Germany, China and Japan. The results show that the growth of market sale affects the innovation scale in the US, Germany and Japan. Also, there is a bidirectional relationship between PV market sales and manufacturing development in the US and Germany. Lin (2011) investigated the key development factors that create a competitiveness in the solar PV industry in Taiwan. Lin indicated that local demand conditions, government support, and related supporting industries have a strong influence on the solar PV industry. Branker et al. (2011) calculated the levelized cost of electricity (LCOE) generation by solar PV for a case study in Canada. They 
found that solar PV has already have met the grid parity in some locations, and that the feasibility of solar PV systems will gradually increase as it expands geographically.

Table (3): Empirical research about power generated by solar power technology

\begin{tabular}{|c|c|c|}
\hline Authors & Subject & Result \\
\hline $\begin{array}{l}\text { Frankl et al. } \\
\text { (1997) }\end{array}$ & $\begin{array}{l}\text { Life cycle analysis of } \\
\text { PV systems in } \\
\text { buildings }\end{array}$ & $\begin{array}{l}\text { They estimated } \mathrm{CO}_{2} \text { yields of } 2.6 \text { and } 5.4 \text { for } \\
\text { conventional PV power plants and building-integrated } \\
\text { systems. }\end{array}$ \\
\hline $\begin{array}{l}\text { Oliver and } \\
\text { Jackson (1999) }\end{array}$ & $\begin{array}{l}\text { Market for } \\
\text { photovoltaic }\end{array}$ & $\begin{array}{l}\text { Satellites, remote industrial, remote communities, solar } \\
\text { home systems, remote houses, and consumer products } \\
\text { could be considered niche markets for solar PV. }\end{array}$ \\
\hline $\begin{array}{l}\text { Nieuwenhout } \\
\text { (2001) }\end{array}$ & $\begin{array}{l}\text { Experience with solar } \\
\text { home systems in } \\
\text { developing countries }\end{array}$ & $\begin{array}{l}\text { Lack of user experience, negative impacts of subsidies, } \\
\text { limited choice of size, and insufficient market } \\
\text { transparency appear to present difficulties. }\end{array}$ \\
\hline $\begin{array}{l}\text { Kolhe et al. } \\
\text { (2002) }\end{array}$ & $\begin{array}{l}\text { Economic feasibility } \\
\text { of solar PV compared } \\
\text { with diesel in India }\end{array}$ & $\begin{array}{l}\text { PV systems have the lowest cost up to } 15 \mathrm{kWh} \text { and can } \\
\text { be increased to } 68 \mathrm{kWh} / \text { day. Break-even point } \\
\text { increases if the cost of PV decreases and diesel costs } \\
\text { increase. }\end{array}$ \\
\hline Waldau (2006) & $\begin{array}{l}\text { European PV in } \\
\text { worldwide comparison }\end{array}$ & $\begin{array}{l}\text { Reliable political framework is required to ensure } \\
\text { returns on investment and need more research to find } \\
\text { cost effective materials, device designing, and increase } \\
\text { efficiency. }\end{array}$ \\
\hline $\begin{array}{l}\text { Nawaz and } \\
\text { Tiwari (2006) }\end{array}$ & $\begin{array}{l}\text { ergy analysis of PV } \\
\text { sed on macro- and } \\
\text { cro level in India }\end{array}$ & $\begin{array}{l}\text { It is estimated that EPBT is in the range of } 7-26 \text { years } \\
\text { and } \mathrm{CO}_{2} \text { emission reductions by existed technology are } \\
\text { calculated in the range of } 18-160 \mathrm{~kg} / \mathrm{m}^{2} / \text { year. }\end{array}$ \\
\hline $\begin{array}{l}\text { Fthenakis and } \\
\text { Kim (2007) }\end{array}$ & $\begin{array}{l}\text { GHG emissions from } \\
\text { solar and nuclear } \\
\text { power }\end{array}$ & $\begin{array}{l}\text { GHG emissions (based on } \mathrm{CO}_{2} \text { equivalent) are } 22-49 \\
\mathrm{~g} / \mathrm{kWh} \text { (average US) and } 17-39 \mathrm{~g} / \mathrm{kWh} \text { (southwest) for } \\
\text { solar energy and } 16-55 \mathrm{~g} / \mathrm{kWh} \text { for nuclear power. }\end{array}$ \\
\hline Ito et al. (2008) & $\begin{array}{l}\text { Study on cost and life } \\
\text { cycle analysis for very } \\
\text { large scale PV }\end{array}$ & $\begin{array}{l}\text { EPBT is } 1.5-2.5 \text { years and } \mathrm{CO}_{2} \text { emission rate is 9-16 } \\
\mathrm{g} / \mathrm{kWh} \text {. Generation cost is estimated } 11-12(19-20) \text { US } \\
\text { Cents/kWh for using 2(4) USD/W PV modules. }\end{array}$ \\
\hline $\begin{array}{l}\text { Fthenakis et al. } \\
\text { (2008) }\end{array}$ & $\begin{array}{l}\text { Emissions from PV } \\
\text { life cycle }\end{array}$ & $\begin{array}{l}\text { Thin-film cadmium telluride has the fewest emissions } \\
\text { among the four types of technology. The differences in } \\
\text { emissions for various PV technologies are too small. }\end{array}$ \\
\hline $\begin{array}{l}\text { Feltrin and } \\
\text { Freundlich } \\
\text { (2008) }\end{array}$ & $\begin{array}{l}\text { Material consideration } \\
\text { for terawatt level } \\
\text { deployment of PV }\end{array}$ & $\begin{array}{l}\text { In spite the availability of silicon, crystalline Si-based } \\
\text { solar cells could not be reach the terawatt level easily } \\
\text { in a large scale-up of technology. }\end{array}$ \\
\hline $\begin{array}{l}\text { Raugei and } \\
\text { Frankl (2009) }\end{array}$ & $\begin{array}{l}\text { Life cycle impacts and } \\
\text { costs of PV systems }\end{array}$ & $\begin{array}{l}\text { If economic incentives are continued for the next two } \\
\text { decades, PV systems are likely to play a significant role } \\
\text { in the future energy mix. }\end{array}$ \\
\hline $\begin{array}{l}\text { Fthenakis et al. } \\
\text { (2009) }\end{array}$ & $\begin{array}{l}\text { Feasibility for solar } \\
\text { energy to supply the } \\
\text { energy needs of the } \\
\text { US }\end{array}$ & $\begin{array}{l}\text { Solar power has the capability to supply } 69 \% \text { of total } \\
\text { electricity and } 35 \% \text { of total energy demands in US by } \\
2050 \text {. It could be increased to } 90 \% \text { by } 2100 \text {. }\end{array}$ \\
\hline $\begin{array}{l}\text { Huo et al. } \\
\text { (2011) }\end{array}$ & $\begin{array}{l}\text { Relationship between } \\
\text { PV market and its } \\
\text { manufacturing }\end{array}$ & $\begin{array}{l}\text { Growth of market sale affects the innovation scale in } \\
\text { the US, Germany and Japan. Feasibility of solar PV } \\
\text { system will be increased in the future as it expands } \\
\text { geographically. }\end{array}$ \\
\hline $\begin{array}{l}\text { Branker et al. } \\
\text { (2011) }\end{array}$ & $\begin{array}{l}\text { Solar PV levelized } \\
\text { cost of electricity }\end{array}$ & $\begin{array}{l}\text { Solar PV already met grid parity in some locations due } \\
\text { to cost reduction. Feasibility of solar PV system will be } \\
\text { increased in the future as it expands geographically. }\end{array}$ \\
\hline
\end{tabular}




\subsection{Geothermal}

Geothermal is a type of thermal energy generated and stored within the Earth. It has been used throughout history for bathing, heating and cooking. Geothermal energy is created by radioactive decay, with temperatures reaching $4,000^{\circ} \mathrm{C}$ at the core of the Earth. While geothermal energy is available worldwide, there is an important factor called the geothermal gradient that indicates whether a region is a favored place for enactment. It measures the rate at which the temperature increases as the depth of the Earth increases. For example, the average geothermal gradient in France is $4^{\circ} \mathrm{C} / 100 \mathrm{~m}$ with a range of $10^{\circ} \mathrm{C} / 100 \mathrm{~m}$ in the Alsace region to $2^{\circ} \mathrm{C} / 100 \mathrm{~m}$ in the Pyrenees Mountains. In Iceland and the volcanic regions, the gradient can reach as high as $30^{\circ} \mathrm{C} / 100 \mathrm{~m}$ (Ngô and Natowitz, 2009).

The geothermal gradient is not the only tool used to measure the accessibility of geothermal energy. The permeability of rocks, which determines the rate of flowing heat to the surface, is considered to be another important measure in the availability of geothermal energy. Geothermal energy has a major advantage compared to wind and solar energy in that it is available 24 hours a day through the year. According to Ngô and Natowitz (2009), the estimated $\mathrm{CO}_{2}$ emissions produced by geothermal resources is $55 \mathrm{~g} / \mathrm{kWh}$ when utilizing data from a survey of $73 \%$ of the geothermal power plants. There is the potential that this value could be decreased to zero if geothermal fluid is re-injected into the ground. A total of 24 countries are currently using geothermal power plants. The total installed capacity was 11 GW in 2011. Figure 3.7 shows the cumulative installed geothermal power capacity worldwide, based on the report by BP (2012).

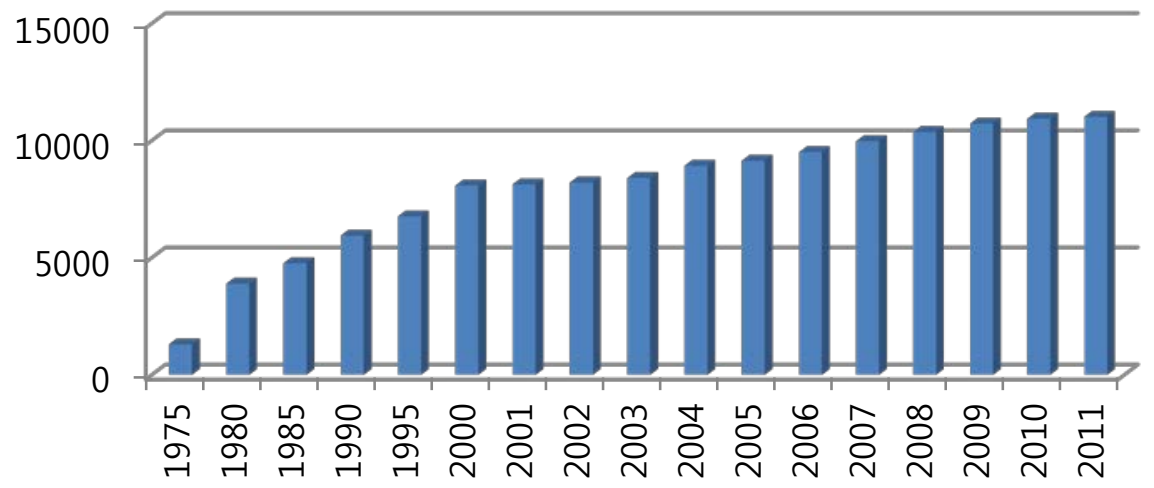

Figure (7): Cumulative installed geothermal capacity, 1975-2011 (in MW)

Costa Rica, Turkey and Iceland have increased their geothermal capacities in 2011, over their 2010 capacities, by 25.3, 21.2 and 15.7 percent, respectively. The majority of geothermal worldwide capacity (GW) has been installed in 8 countries: the United States (3.1), the Philippines (almost 2.0), Indonesia (1.2), Mexico (0.9), Italy (0.9), New Zealand (0.8), Iceland (0.7), and Japan (0.5) (BP, 2012). The geothermal capacity is expected to increase with advancements in the co-production of geothermal power by using water through oil and gas wells throughout 2015. Figure 3.8 shows the estimated investment needs for geothermal development by 2050, for OECD and non-OECD countries (IEA, 2012c). 


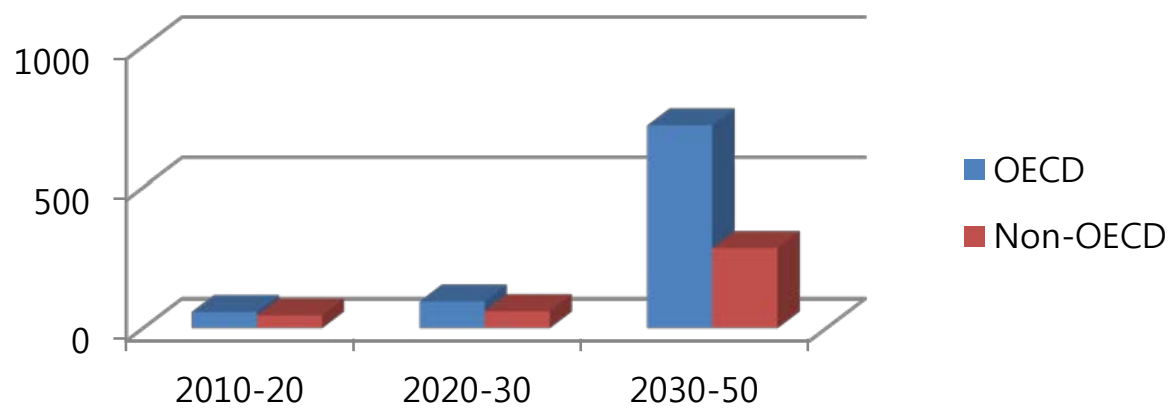

Figure (8): Investment to achieve geothermal generation targets, 2010-2050 (billions USD)

Fridleifsson and Freeston (1994) investigated geothermal energy development based on worldwide experiences, and they forecasted total investment costs of 15-20 billion dollars in geothermal energy throughout the world over the next decade. However, this estimate increased fivefold in the IEA report, which estimated the total investment costs to be 104 billion dollars worldwide between the years 2010-2020 in order to meet the desired targets (IEA, 2012c). Following Fridleifsson and Freeston, who consider geothermal independence from weather conditions and storage capability, geothermal energy could be used for both base and peak load power plants. They claimed that environmental problems created by the release of steam, and gases, as well as hot water into the river, could be reduced by advanced technologies. In order to use geothermal energy with readily available technology in developing countries, difficulties associated with the lack of finances and knowledge of the infrastructure need to be resolved.

Murphy and Niitsuma (1999) discussed strategies to compensate the higher costs of geothermal electricity due to the desirable environmental benefits. They suggested the use of fiscal policy measures to increase the feasibility, including the use of a carbon tax and monetizing the advantages of geothermal. They pointed to Japan, Indonesia and the Philippines as countries with high geothermal growth rates, in part due to supportive policies instituted by their governments. Stefansson (2002) applied a statistical methodology and utilized data from Iceland to estimate the investment costs required to build a geothermal power plant. The total investment cost of geothermal power plants, in the range 20-60 MW, is estimated to be $1,267 \mathrm{USD} / \mathrm{kW}$ in a known field and 1,440 USD/kW in an unknown field.

Lund et al. (2005) reviewed worldwide applications of geothermal energy using data from 72 countries. Their results showed that using 273,372 TJ (terajoule)/year of geothermal energy, and assuming there are $6.06 \times 10^{9} \mathrm{~J}$ of energy for each barrel of oil, could save 128.9 million barrels of oil, or 19.2 million tons, per annum. They also argued that there will be an additional savings of 41.2 million barrels (6.2 million tons) of fuel oil and 7 million tons of carbon emissions if the use of a geothermal heat pump is considered during the cooling mode.

Frick et al. (2010) applied a life cycle analysis method to geothermal power generation from an enhanced geothermal system (EGS) with low temperature reservoirs in order to quantify the effect of geological conditions on the environment. The results show that the life cycle of a geothermal binary power plant is determined by the materials and energy inputs. Therefore, successful access to a reservoir for minimum drilling is an important factor on having low environmental impacts. There is evidence that even less favorable geothermal heat and power generation could contribute to an energy system and enhance sustainability. In a related study, Saner et al. (2010) analyzed energy consumption and GHG emissions and then applied a life cycle assessment to examine the environmental impacts due to an installed ground source 
heat pump (GSHP) for extracting geothermal energy. The results indicate a 31-88\% emission savings compared to conventional heating systems.

Purkus and Barth (2011) analyzed the German geothermal industry, with an emphasis on the importance of political support and framework conditions in the electricity market. They argued that even with the disadvantages of high investment costs and the risk of insufficient heat of geothermal technology, the advantage of non-intermittency could enable it to be a reliable base load power supply. Kaya et al. (2011) investigated the re-injection in geothermal fields employing data from 91 geothermal power plants (worldwide) and found that a reinjection plan is required to reduce the risk of groundwater contamination. The results showed that the response of the geothermal reservoir to different re-injection strategies depends on the geothermal system.

In a recent study, Chamorro et al. (2012) reviewed the status of geothermal energy (worldwide) and found that high temperature technologies (flash and dry steam) are the most developed geothermal power generation technologies. They defined four plant, models, including 1FMP (single flash), 2FMP (double flash), 3FMP (triple flash) and DSMP (dry steam), to analyze various geothermal systems. The results showed that the DSMP model has the highest NPV amount (1,013.6 million dollars) and IRR factor (22.8\%). Also, the cost of electricity is estimated to be 29.38 \$ $/ \mathrm{MWh}$ for the DSMP model, the minimum among the different models.

Table (4): Empirical research about power generated by geothermal energy technology

\begin{tabular}{|l|l|l|}
\hline Authors & Subject & Result \\
\hline $\begin{array}{l}\text { Fridleifsson and } \\
\text { Freeston (1994) }\end{array}$ & $\begin{array}{l}\text { Geothermal energy } \\
\text { R\&D }\end{array}$ & $\begin{array}{l}\text { 15-20 billion dollars for total investment of } \\
\text { geothermal energy in the world during the next decade } \\
\text { is needed. It could be used both for base and peak } \\
\text { power plants. }\end{array}$ \\
\hline $\begin{array}{l}\text { Murphy and } \\
\text { Niitsuma (1999) }\end{array}$ & $\begin{array}{l}\text { Strategies for } \\
\text { compensating higher } \\
\text { costs of geothermal }\end{array}$ & $\begin{array}{l}\text { They suggested some fiscal policy measures, such as a } \\
\text { carbon tax and monetizing the advantages of } \\
\text { geothermal electricity. }\end{array}$ \\
\hline $\begin{array}{l}\text { Stefansson } \\
(2002)\end{array}$ & $\begin{array}{l}\text { Investment cost for } \\
\text { geothermal power } \\
\text { plants }\end{array}$ & $\begin{array}{l}\text { Total investment cost of geothermal power plants (in } \\
\text { the range of 20-60 MW) is estimated to be 1,267 } \\
\text { USD/kW in a known field and 1,440 USD/kW in an } \\
\text { unknown field. }\end{array}$ \\
\hline $\begin{array}{l}\text { Lund et al. } \\
\text { (2005) }\end{array}$ & $\begin{array}{l}\text { Application of } \\
\text { geothermal energy }\end{array}$ & $\begin{array}{l}\text { Using 28,268 MWt installed capacity in 2005, the } \\
\text { estimated energy savings could be 128.9 million } \\
\text { barrels of oil or 19.2 million tons of oil per annum. }\end{array}$ \\
\hline $\begin{array}{l}\text { Frick et al. } \\
\text { (2010) }\end{array}$ & $\begin{array}{l}\text { Life cycle assessment } \\
\text { of geothermal binary } \\
\text { power plants }\end{array}$ & $\begin{array}{l}\text { The life cycle of a geothermal binary power plant is } \\
\text { determined by materials and energy inputs. Reservoir } \\
\text { for minimum drilling lowers environmental impacts. }\end{array}$ \\
\hline $\begin{array}{l}\text { Saner et al. } \\
\text { (2010) }\end{array}$ & $\begin{array}{l}\text { Life cycle perspectives } \\
\text { on geothermal systems }\end{array}$ & $\begin{array}{l}\text { CO emission equivalent of 63 tons for a life cycle of } \\
\text { 20 years, means a 31-88\% emission savings for } \\
\text { Europe, compared to conventional heating systems. }\end{array}$ \\
\hline $\begin{array}{l}\text { Purkus and } \\
\text { Barth (2011) }\end{array}$ & $\begin{array}{l}\text { Geothermal power } \\
\text { production in future } \\
\text { electricity markets }\end{array}$ & $\begin{array}{l}\text { High investment costs and the risk of insufficient heat } \\
\text { are disadvantages of this technology, but non- } \\
\text { intermittency enable it to be a reliable supply of base } \\
\text { load power. }\end{array}$ \\
\hline $\begin{array}{l}\text { Kaya et al. } \\
\text { (2011) }\end{array}$ & $\begin{array}{l}\text { A re-injection plan is required to reduce the risk of } \\
\text { groundwater contamination. It is an environmental } \\
\text { friendly method of waste water disposal. }\end{array}$ \\
\hline
\end{tabular}




\begin{tabular}{|l|l|l|}
\hline Authors & Subject & Result \\
\hline $\begin{array}{l}\text { Chamorro et al. } \\
\text { (2012) }\end{array}$ & $\begin{array}{l}\text { Energy, environmental } \\
\text { and economic study of } \\
\text { geothermal technology }\end{array}$ & $\begin{array}{l}\text { Dry steam model plant (DSMP) has the highest NPV } \\
\text { and IRR factor with 1,013.6 M\$ and 22.8\%, } \\
\text { respectively. Also, the cost of electricity at 29.38 } \\
\text { \$/MWh for DSMP is lowest. }\end{array}$ \\
\hline
\end{tabular}

\subsection{Other renewable sources}

There are other types of renewable energy sources including biomass, ocean waves and tides. Biomass is defined as living plants and organic waste which are made by plants, human, marine life, and animals. Based on Tester (2005), the main advantage of biomass is availability, as it can be readily found in all places. Many kinds of energy can be produced from biomass: electricity, cooking heat, chemical feedstock, etc. As a feedstock, biomass has a lower sulfur content than coal and a lower emission is produced by combustion. In early 2000, the United States had an installed capacity of 11 GW from biomass including the forest product and agricultural industry, municipal and solid waste industry, and other sources (Ngô and Natowitz, 2009).

Extracting energy from the ocean is considered to be an interesting option, due in part to the wide availability of ocean sources. There are six different resources which are available from oceans: offshore wind energy, wave power, marine current energy, ocean thermal energy conversion, tidal power, and osmotic power. The Bay of Fundy has the largest tidal range in the world that enables it to support a power station with a capacity of $2 \mathrm{GW}$ or more (Tester, 2005). In this paper we considered hydro, wind, solar and geothermal energy, because of their main contribution to renewable power generation.

\section{Energy efficiency technologies}

As previously mentioned, there are two main solutions to reducing $\mathrm{CO}_{2}$ emissions and to overcoming the climate change problem: replacing fossil fuels with renewable energy sources as much as possible and through enhancing energy efficiency. We discussed the state of the art methods for technical and economic feasibility of expanding the use renewable energy sources and the possibility of substitution in the first part of this review. In this part that follows, we discuss energy efficiency technologies. Energy efficiency for an electricity network could be considered in different stages, such as the power generation, transmission, distribution and consumption. The different technologies that are currently available include electric vehicles (EV), combined heat and power (CHP), virtual power plants (VPP) and smart grids, each of which are discussed below.

\subsection{Electric Vehicles}

Electric vehicles (EV, including the battery, fuel cell, and hybrid types) have the potential to be considered viable options for both electricity storage and power generation. Considering that the transportation sector is one of the main sources of emissions, improving fuel efficiency enables us to achieve the largest fuel savings and $\mathrm{CO}_{2}$ reduction in the short term. Thus, the increased usage of EVs and increasing their share of the vehicle fleet can play a key role in the long term. IEA (2012c) forecasted an increased share of plug-in hybrid electric vehicles (PHEV) over the next two decades, with a total increase of up to $50 \%$ by 2050 . "In long-term, smart grid technology may enable EVs to be used as distributed storage devices, 
feeding electricity stored in their batteries back to the system when needed (vehicle to grid), to help provide peak-shaving capability.”(IEA, 2012e)

Ford (1995) examined the impact of the large scale use of electric vehicles in southern California and concluded that Southern California Edison (a power company in the area) was able to accommodate a large number of EVs with their existing capacity, particularly if the charging system was managed by smart control. Ford argued that EVs can improve load management, enhance efficiency and save energy. He also calculated that EVs are able to reduce emissions at a value of around 9,000 USD per vehicle. Kempton (1997) calculated the present value costs for an EV owner and the benefits to utilities. Based on the results, all three vehicle/battery combinations are cost-effective power sources during the peak time for the short-term. He argued that if a part of the transportation section is utilized by electric vehicles with connections to the electricity network, there will be less demand for base-load generation. In addition, the use of intermittent renewable energy sources becomes more applicable due to a lack of concern about the time-of-day match between demand and supply.

Kempton and Tomic (2005) investigated the systems and procedures required to use energy in vehicles, as well as the implementation of vehicle to grid (V2G) technology. The most important role of V2G could be its support to renewable energy in the emerging power markets through managing load and supply fluctuations. They argued that after initially tapping EVs for their high value, market saturation and cost reduction, V2G fleets could be used as storage capacity for renewable energy power generation. Tomic and Kempton (2007) examined the economic feasibility of battery-electric vehicles to supply power for a particular market in the US. The results show that V2G electricity is able to provide a significant income flow, contributing to the feasibility of grid connected vehicles and furthering support for adoption. Lund and Kempton (2008) evaluated the integration of renewable energy into the transport and electricity sectors by V2G. They applied a model to analyze energy integration for electricity, transport and heating. V2G technology has been found to provide storage for the matching time of generation and time of load. Adding EVs and V2G technology to power networks enables the system to be integrated with wind electricity without extra power generation and also makes a significant reduction in $\mathrm{CO}_{2}$ emissions.

Steenhof and McInnis (2008) analyzed three scenarios to evaluate the impacts of increasing ethanol 85, hydrogen, and electricity powered vehicles into the passenger transportation fleet starting in 2010, and reaching $100 \%$ of the new vehicle market by 2050 . The results show that $\mathrm{CO}_{2}$ emissions will be reduced by $153 \mathrm{Mt}$ from the use of electric vehicles to $156 \mathrm{Mt}$ from the use of hydrogen fuel cell vehicles by the year 2050. It is also forecasted that ethanol driving cars will be cellulose based by 2050, generating a significant reduction in $\mathrm{CO}_{2}$ emission, but still producing an unsustainable amount of crop residues.

Andersen et al. (2009) introduced an intelligent electric recharging grid operator (ERGO) for the creation of a market that coordinates the production and consumption of renewable energy. They argued that an ERGO model could overcome the problems of GHG emissions and power fluctuations through converting EVs to be distributed storage devices for electricity. The introduction of V2G distributed power sources and IT intelligence to the grid, the creation of virtual power plants through distributed resources and the provision of new applications for carbon credits have been documented benefits associated with the ERGO model.

Weiller (2011) applied a model that examines the impacts of different charging scenarios for PHEVs in the United States on electricity demand, accounting for the time of day and charging place. The results show that possibility of being able to charge in places other than 
the home increases the fraction of daily energy use of PHEV from 24\% to 29\% (1.5-2.0 $\mathrm{kWh} /$ day). Based on the results, PHEV-20 (vehicles with a 20 mile range) shifts $45-65 \%$ of the miles traveled to electricity, compared to $65-80 \%$ for PHEV-40. Furthermore, it is surmised that PHEVs enable US drivers to cut gasoline consumption by more than $50 \%$ through shifting $45-77 \%$ of the miles traveled to electricity power. Weiller indicated that PHEVs could be considered a cost-effective solution when we compare electricity costs at about $\$ 0.03 /$ mile $(\$ 0.13 / \mathrm{kWh}$ ) to gasoline which costs $\$ 0.12 /$ mile (\$3/gallon). Environmental and transportation policy, as well as public financial incentives regarding a carbon tax, can influence the early and comprehensive implementation of EVs.

\subsection{Combined Heat and Power}

Cogeneration, or combined heat and power (CHP), is the use of heat and electric power together. It is expected to have a substantial gain in efficiency over each source separately. Most power distribution companies supply only electricity, not hot water or steam. Considering that almost $30-40 \%$ of a country's total energy load is used for heating, CHP is an efficient use of fuel when a portion of the energy is discarded as waste heat. It captures some or all of the waste energy as a by-product for heating. In Reykjavik and New York, end users are able to purchase both electricity and thermal energy from a utility company (Tester, 2005). An example of cogeneration is the CHP unit in Avedore, Denmark which is a multifuel plant (Ngô and Natowitz, 2009). Shipley et al. (2008) calculated that increasing the CHP capacity of the United States to $20 \%$ by 2030 would lead to a reduction of 5.3 Quads (Quadrillion British Thermal Units) of energy consumption and 848 MMT of carbon dioxide emissions. Based on their findings, the United States would save more than 1.9 Quads of fuel consumption and 248 million metric tons of carbon dioxide emissions by employing CHP. According to the WEO (2012) report, the average efficiency of power plants is $41 \%$ worldwide, with almost $60 \%$ of the primary energy being converted to waste heat (IEA, 2012e). CHP could transform a significant part of the waste heat into a positive economic value for industrial processes or heating in residual and commercial buildings. It is estimated that new CHP units could improve energy efficiency to a level greater than $85 \%$.

Madiment and Tozer (2002) investigated the application of combined cooling heat and power (CCHP) for supermarkets in the UK and compared it to the energy savings/capital cost of conventional technology. The results show that CCHP is able to provide a significant amount of primary energy while reducing $\mathrm{CO}_{2}$ emissions compared to conventional schemes, but it is also believe to be competitive with more efficient technologies in long term. They argued that new technologies, such as fuel cells, could provide improvements in energy efficiency for CCHP in refrigeration.

Hawkes and Leach (2007) examined cost effective operating strategies of three alternatives micro-CHP technologies (Sterling engine, gas engine and solid oxide fuel cell-based (SOFC) system) for residential application in the UK. They evaluated the economic and environmental attributes on the abovementioned technologies for heat-led, electricity-led and least-cost operating strategies. The results showed that the SOFC-based system had the maximum operating cost and the largest $\mathrm{CO}_{2}$ emission reduction following the least-cost operating strategy. You et al. (2009) examined the electricity export capability of aggregated micro-CHP units as a virtual power plant (VPP) through participation in the electricity wholesale market. They found that the export capability of micro-CHP systems strongly depends on technical parameters, associated energy price, and the demand profile. Based on applied model, it is surmised that the marginal price for a micro-CHP system is higher than 
the spot price for most of the year.

Kiviluoma and Meibom (2010) analyzed the impact of variable power generation by wind turbines and EVs stored electricity on the ability to enhance the flexibility of a power grid. Based on the results, CHP units could be viable options for making power systems more flexible in terms of production and the use of heat. Christidis et al. (2012) investigated the contribution of heat storage to optimize CHP units in liberalized electricity markets, applying a model that measures the economic potential and optimal capacity of heat accumulators. They concluded that separating electricity production and heat demand could provide a profitable payback period for storage devices in the proposed energy system.

\subsection{Virtual Power Plant}

A Virtual Power Plant (VPP) is a cluster of distributed energy resources, such as micro-CHP, wind turbines, and solar photovoltaic panels, which are controlled and managed by a central control unit. The term distributed energy resources (DER) can be used for fossil or renewable energy fuels. A DER system has been defined in order to overcome energy waste problems due to long distances and transmission losses. Therefore, DERs are generally located close to the distribution networks. The concept of VPP is used for DER integration. According to the Europe FENIX project (Kieny et al., 2009), there are two types of VPPs, the Commercial VPP (CVPP) and the Technical VPP (TVPP). DERs can simultaneously be part of both a CVPP and a TVPP. A commercial VPP is defined as a portfolio that could be used by a DER to participate in electricity markets. CVPPs can represent a DER from any geographic place in an electricity network. A technical VPP enables operators to facilitate DER energy capacity and optimize the power balance in the system with the minimum cost (Pudjianto et al., 2007).

The share of distributed generation (DG) in an electricity network is increasing in importance and VPP is considered to be an emerging technology that enhances energy efficiency. Schulz et al. (2005) analyzed the technical and economic feasibility of operating a VPP with microCHP units. They explained that, due to Germany's plan to abandon nuclear power plants until 2020, a part of the new capacity should be comprised of renewable energy sources and CHP utility, which are considered DG units. VPP is an alternative to the management of these units, as of the absence control needs provides an advantage for renewable energy technology. Based their findings, the power generated by an individual owner is too small to supply, with the amount of the power output needing to be $30 \mathrm{MW}$ or higher based on existing regulation. A VPP operator can integrate a large number of DERs and provide $30 \mathrm{MW}$ through aggregating 6,000 micro-CHP units, each with a power output of $5 \mathrm{~kW}$. They estimated that every unit is charged 300 Euros for connection into the integrated system. Ruiz et al. (2008) applied a model to manage a VPP made up of a large number of customers with controlled home appliances in order to optimize load reduction over a certain time schedule.

Jansen et al. (2010) examined an architecture and communication pattern for employing a large number of electric vehicles to be integrated into a VPP system. They argued that EVs have a strong potential to be a component of the electricity network if the fleet of vehicles is managed appropriately. It is indicated that intelligence is required to optimize the charging of $\mathrm{EV}$ batteries in order to manage the integration of EVs into the electricity network. You et al. (2009) proposed a market-based VPP model constituted with DER units which have access to electricity markets. Based on the model, general bidding and price signals are considered two operation scenarios performed by one market-based virtual power plant. Haussmann et al. (2010) developed a mathematical optimization model for the management of CHPs. Considering the main task of a VPP is to increase generated electricity by DG units, the 
operation of individual generators should be optimized. Next, their contribution to output of VPP is calculated. They applied this model for a local heating system populated by 5 CHP units, and their results indicate a 10\% increase in benefits compared to a general CHP system.

\subsection{Smart meter}

The most important objective for power generation companies in demand side management is to reduce peak demand during a certain period. In this regard, a smart meter is a device to record the consumption of electricity in hourly intervals and the information is monitored by both the utility and customer. A smart meter is able to have two way communication and intelligence management for home appliances. Hartway et al. (1999) examined the application of smart meters and customer choice control in order to show that a time-of-use (TOU) strategy can be beneficial for a utility company. The results show that the TOU rate option could result in a $107 \mathrm{kWh}$ energy savings for each customer per year. They calculated the annual savings on customers' electricity bills to be $\$ 77$ with a cost savings of $\$ 134$ per customer for the utility company. Applying smart meters could facilitate a significant change in the energy efficiency of electricity networks.

Faruqui et al. (2007) calculated that a decrease in the US peak demand through the installation of advanced metering infrastructure could have a substantial savings in generation, transmission, and distribution costs. For example, a 5\% decrease is enough to eliminate 625 peak load power plants and their associated infrastructure, saving roughly $\$ 3$ billion a year. Karnouskos et al. (2007) indicated that smart meters and advanced metering infrastructure allows one to adapt production and consumption proactively. They argued that smart meters could provide new opportunities in the electricity network and system integration through data processing and making decisions based on capabilities. This role enables managers and policy makers to take advantage of real-time data. It is believed that smart meters could be a gateway for home appliance communication through the internet that will enable the use of advanced communication capabilities in the future.

Faruqui et al. (2010) quantified the long term costs and benefits of investing in dynamic pricing and installing smart meters for the EU. They estimated that the installation costs of smart meters will be 51 billion Euros with operational saving of 26-41 billion, creating a gap of around 10-25 billion Euros. In their view, smart meters have the capability to cover this gap through the use of dynamic pricing and reducing peak demand. They suggested that policy makers and utility companies should increase the adoption rate by applying innovative policies that encourage customers to participate. It is expected that the amount of saving due to the reduction in capacity and transmission costs will be 67 billion, if $80 \%$ of customers reduce their electricity consumption during peak hours.

Depuru et al. (2011) examined the different features and technologies to be integrated with smart metering to figure out what is required to implement a network appropriated for smart grid communication. It is indicated that the worldwide integration of smart meters is estimated to reach nearly 212 million units by 2014. They indicated that Home Area Networks (HAN) technology could support PHEVs and DG units in the communication network. Considering a significant growth rate of PHEV's penetration in the future, there could be a substantial increase in the demand for smart meter application. Due to increasing fuel prices and high initial costs of developing conventional infrastructure for the supply side of an electricity network, improvements in energy efficiency and the implementation of demand response (DR) program through smart metering are attractive options (see Heshmati, 2014). Baltimore Gas and Electric has estimated that the capital cost of a DR program at 
$\$ 165 / \mathrm{kW}$ is much less than building new peak demand generation facilities at $\$ 600-800 / \mathrm{kW}$ (Vojdani, 2008).

Krishnamurti et al. (2012) discussed consumers' expectations and their behavioral decisions, applying a model to measure the impacts of smart meter installation on their diffusion. Based on the results, there is a misconception on the part of the consumers about the impact of smart metering integration. They suggested that this misconception could be remedied by the electric utilities, who can explain the potential risks and benefits clearly and ease the concerns about privacy and loss of control. McKenna et al. (2012) analyzed consumer privacy concerns about smart metering and some applications of smart meters' data required for the electricity industry. They examined how much sensitivity is acceptable for obtaining data and investigated whether the leakage of personal data can be minimized or avoided. Based on the results, it is suggested that power supply requirements for sensitive smart metering could be reduced by applying appropriate privacy techniques. Privacy concerns have a strong potential to delay smart meter penetration.

McHenry (2013) discussed the technical and governance considerations for smart meter infrastructures including the technical and non-technical requirements, costs and benefits of smart meter infrastructures, and impact of smart meter installation on stakeholders. He argued that the full benefits of advanced metering infrastructure (AMI), along with other technologies, enable stakeholders to take advantage of intelligent management in order to minimize costs, improving efficiency and remote monitoring. Although the potential benefits of AMI could be significant, it is stated that scale of smart meter investment and its distribution among power users and providers is considered as unprecedented challenge for policy makers.

\section{Main drivers for using renewable energy technologies}

\subsection{Energy security}

Concerns about the security of the energy supply were raised after the Arab oil embargo in 1973. Additional factors included high oil prices, the increasing dependency on oil imports, the depletion of fossil fuels, an increasing competition from emerging economies, political instability in major oil producers and a high impact due to any disruption in energy supply on developed and rapidly developing countries (Bhattacharyya, 2011). The level of insecurity was shown by the risk of supply disruption and estimated costs associated with security improvement. Owen (2004) called the security of energy supplies a key requirement for the economic, environmental and social objectives of sustainable development policies. In his view, the energy security risk could be classified as strategic and domestic system risks. He also defined damage costs and control cost as potential costs imposed by energy insecurity. He argued that the damage cost could be evaluated by potential decreases in GNP, but that it is difficult to estimate how much money is spent as control costs. For example, it's very difficult to estimate how much money has been spent by the United States to control oil security.

Concerns about climate change had an additional impact on energy security objectives. The diversification of the energy supply to promote energy security could be considered a policy for climate protection (Bhattacharyya, 2011). Before the era of industrialization when coal was used as the main source of energy (mid- $19^{\text {th }}$ century), renewable energy sources were widely used. There is the potential to use renewable energy (e.g., hydropower, solar, wind and biomass) around the world, which enables the supply of clean energy and enhances the long- 
term sustainable energy supply (Asif and Muneer, 2007). Renewable energy sources may have security issues as well, a result of the intermittent characteristics for some energy types including solar and wind energy, as well as the possibility of low rainfall for hydropower consumption. Therefore, such factors should be considered in the sectors that heavily rely on these sources. Renewable energy technologies are beneficial for both energy producing and consuming countries. Renewable energy technologies reduce the domestic demand for fossil fuels and increase the export capability. For example, Iran was the $4^{\text {th }}$ largest producer of natural gas worldwide in 2011, but it was a net importer because of high domestic demand. Also, a high dependency to import could create a serious problem if there is any kind of disruption in the energy supply. For example, European countries are dependent on Russia to import natural gas, and in turn, experienced great difficulties when Russia cut off the gas supply transmitted by Ukraine in 2006.

Furthermore, we should also consider the external costs spent on energy security indirectly in our calculation. Along with storage costs and military expenditures, there is a relatively large externality cost associated with the possibility of accidents at nuclear power plants, as was seen by accidents at Three Mile Island (1979), Chernobyl (1986), and Fukushima Daiichi (2011). Around 6,000 cases of thyroid cancer have been recorded in contaminated regions from the Chernobyl accident to date, and it has been estimated that an additional 10,00040,000 cases of cancer may arise over the next few decades (Hoeve and Jacobson, 2012). The number of accidents at nuclear power plants may be rare, but the economic, social and environmental costs can be extreme. If we include all the external costs in our evaluation, including those related to social and environmental security, renewable energy sources will be feasible.

\subsection{Economic impacts}

The emphases for economic impacts are job creation, industrial innovation and balance of payment. Renewable energy technologies could enable countries with good solar or wind resources to employ these energy sources to meet their domestic demand. Also, renewable energy technologies may even enable these countries to utilize renewable energy sources with long-term export potential. Moreover, the cost of importing fuels can affect economic growth. If these countries could reduce their balance of payment by producing their own renewable energy to replace their dependence on fossil fuels, it could raise the capacity for investment in the other sectors. IEA created a cost-benefit analysis for the investment in low-carbon energy systems based two scenarios: ETP $20126^{\circ} \mathrm{C}$ (6DS), which assumes business as usual, and $2^{\circ} \mathrm{C}$ (2DS), which targets the reduction of carbon dioxide emissions by 50 percent, using 2005 levels as the benchmark. The results estimate that 103 trillion dollars will be saved during the years 2010-2050 by reducing fossil fuels consumption. This calculation is based on the reduction in fossil fuels purchases (214 Gtoe), although the estimate could increase to 150 trillion dollars if the impact of lower fuel prices is taken into consideration (IEA, 2012c).

A main economic driver to the enhancement of renewable energy technologies is their job creation potential. It's estimated that 5 million people work in renewable energy industries. Although, total employment in these industries has continued to increase, the recent global recession, coupled with policy changes, has caused the employment in some countries (e.g., Germany and Spain) to decrease (Martinot and Sawin, 2012). Figure (9) shows the distribution of estimated jobs in renewable energy worldwide by industry based on the GSR 2012 report. 


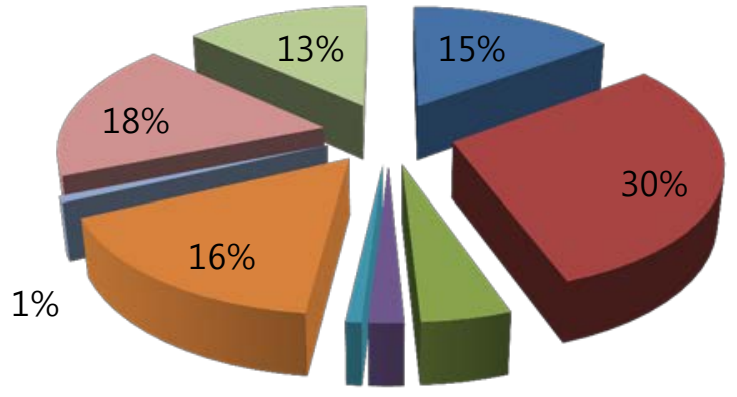

$1 \% 2 \% \quad 4 \%$

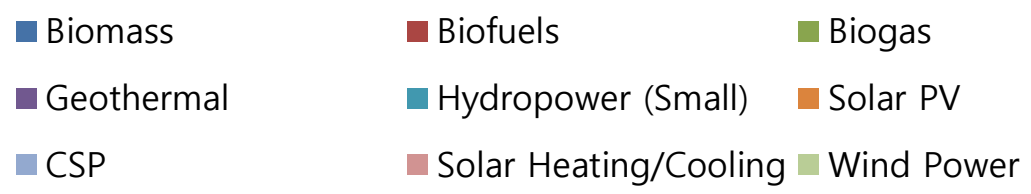

Figure (9): Estimated jobs in renewable energy worldwide, by industry

In the GSR 2012 report, the breakdown of job creation by sector is as follows: 1.5 million workers in the biofuels industry, 820,000 in the solar PV industry and 670,000 in the wind power industry. Currently, more than 1.6 million workers are employed in the renewable energy industry (Martinot and Sawin, 2012). The majority of jobs in renewable energy industries are located in China, Brazil, the United States and the European Union. Germany has been the front runner in Europe in terms of job creation in the renewable energy industry. It has sharply increased its power generation by renewable technologies since the beginning of this century, with a share of almost 15 percent of the total electricity production in 2008 (Frondel et al., 2010). Ragwitz et al. (2009) investigated the gross and net effects of renewable energy policies in the European Union. In particular, they analyzed the past, present and future effects of renewable energy policies on employment and the economy at the overall and member levels. They found that the current economic benefits of the renewable energy sectors can and should be increased in future by improving the existing policies, "in order to reach the agreed target of 20 percent renewable energies in Europe by 2020." They argued that increasing the share of renewable energy sources not only has minimal negative effects on the economy, but that it could also help the economy through job creation and increasing the GDP. From their point of view, the economic advantages of renewable energy could be even higher if external costs were included in calculations.

\section{3 $\mathrm{CO}_{2}$ emission reduction}

Renewable energy technologies could reduce carbon dioxide emissions by replacing fossil fuels in the power generation industry and transportation sector. Life-cycle $\mathrm{CO}_{2}$ emissions for renewable energy technologies are much lower than fossil fuels. The life-cycle balance is also considered to be an important factor in the heat and transportation sectors. Based on an analysis performed by the IEA, renewable power generation enabled countries to save $1.7 \mathrm{Gt}$ of $\mathrm{CO}_{2}$ emissions in 2008, a figure that is more than the total power sector's $\mathrm{CO}_{2}$ emissions in the European region (1.4 Gt) (Ölz, 2011). This analysis shows that hydropower technology constitutes the largest share for saving $\mathrm{CO}_{2}$ emissions with 82 percent, followed by biomass and wind with 8 and 7 percent, respectively. 


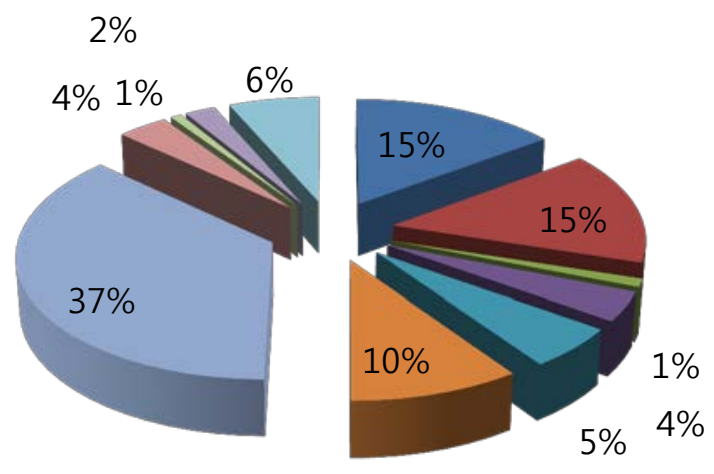

- OECD Europe

- OECD North America

OECD Pacific

Brazil

Russia

India

China

Africa

Middle East

- Other Latin America

Figure (10): Saving in $\mathrm{CO}_{2}$ emissions between no-RE and the 450 ppm scenarios in 2030

According to the IEA analysis, the potential savings for the OECD and BRICS countries is roughly $5.3 \mathrm{Gt}$ in the year 2030, almost the same as is forecasted for power-related $\mathrm{CO}_{2}$ emissions in the WEO 2010 report for the these countries in 2030 under a 450 ppm scenario (5.8 Gt).

Figure (10) shows the $\mathrm{CO}_{2}$ saving under the WEO 450 scenario compared to a no renewable energy scenario in 2030. The key point is that most $\mathrm{CO}_{2}$ savings are concentrated in the OECD countries and China. According to the IEA report, $\mathrm{CO}_{2}$ savings in China on a $450 \mathrm{ppm}$ scenario would be $2.2 \mathrm{Gt}$, constituting 64 percent of the BRICS countries' total saving (Ölz, 2011). Edenhofer et al. (2010) examined the technological feasibility and economic consequences of achieving greenhouse gas targets and found that these targets are low enough to be feasible, both technically and economically. They stated that this crucially depends on the particular technology. For example, the availability of carbon capture storage technology is very important in the removal of $\mathrm{CO}_{2}$ from the atmosphere. Also, they argued that additional political and institutional prerequisites are required to achieve the targets.

\section{Summary and Conclusion}

Ongoing concerns about climate change have made renewable energy sources an important component of the world energy consumption portfolio. Renewable energy technologies could reduce carbon dioxide emissions by replacing fossil fuels in the power generation industry and the transportation sector. Due to negative and irreversible externalities in conventional energy production, it is necessary to develop and promote renewable energy supply technologies. Power generation using renewable energy sources should be increased in order to decrease the unit cost of energy and to make them compatible with a competitive alternative to the conventional energy sources. Two main solutions may be implemented to reduce $\mathrm{CO}_{2}$ emissions and to overcome the problem of climate change: replacing fossil fuels with renewable energy sources as much as possible and enhancing energy efficiency regardless of type. In this review, we considered hydro, wind, solar and geothermal sources, because of their significant contribution to power generated by renewable sources.

Renewable energy production and supply is continuously increasing on the global level. 
Following the drastic increase in oil price and its impacts on both coal and gas prices, a large amount of investment has been made over recent years in renewable energy. These advancements in technology have enabled countries to produce renewable energy in larger quantities and more cost effectively. Due to negative and irreversible externalities associated with conventional energy extraction and consumption, it is necessary to promote and develop renewable energy supply and consumption. The IEA forecasts positive developments in renewable energy sources. They act as substitutes for fossil fuels and reduce emissions. In the short term, some renewable technologies may not be comparable to conventional fuels in the scope of production costs and transmission, but they could be comparable if we consider their associated positive externalities, such as their environmental and social effects. Also, it should be noted that economies of scale could play a key role in reducing the unit cost of production. Transmission and distribution costs and technologies do not differ much among the conventional and renewable energy sources. In this review we have presented detailed facts about the main renewable energy supply technology developments, including hydro, wind, solar, and geothermal in detail and other sources such as biomass, ocean waves and tides in brevity. The emphasis has been on current production capacity and the estimated capacity, as well as development costs which are sunk. We have also presented empirical findings from comparative studies of alternative energy technologies.

Hydro power is the largest renewable energy source for power generation around the world. Despite its large energy generation contribution, its development is difficult due to a high initial fixed investment cost and environmental and population relocation costs. Hydro power is attractive due to a combined supply of water for agriculture, household, recreation and industrial use. Additionally, it can store water and energy that can be used for both base and peak load power generations. The availability of funding, political and market risks, resource allocation priorities and local environmental concerns are considered to be barriers to the development of hydro power capacity. The installed wind power capacity has also been increasing, especially in countries like China, the US, Germany and Denmark. Advantages of wind power plants include the installation as turnkey contracts within a short period, a lower investment compared to nuclear and hydroelectric plants, economies of mass production, an absence of fuel costs and low operation and maintenance costs. The problems associated with the use of wind power include intermittency of wind energy and an added cost for power transmission to users. Generation cost is dependent on location, feasibility and the minimum required speed for wind turbines. China has developed its own solar power capacity, decreasing the cost of generation due to the availability of cheap labor and public subsidies. Another source of the reduced costs is in advances and the high efficiency in concentrated solar power technologies in the US. The negative effects include land, material and chemical use and impacts on buildings' esthetics. The performance is dependent on location. Geothermal energy has been used throughout history for bathing, heating and cooking. The geothermal gradient and permeability of rocks determines its economic implementation feasibility. Unlike wind and solar power, geothermal is continuously available through the year, although technology has some negative environmental effects.

Improved energy efficiency is an important way to reduce energy use, and thereby $\mathrm{CO}_{2}$ emissions, and to overcome the climate change problem. We discussed state of the art methods for the technical and economic feasibility in the implementation of renewable energy sources, as well as the possibility of their combined use and substitution in the first part of this review. In the latter part we discussed energy efficiency technologies. Energy efficiency for electricity networks can be considered in different stages, such as power generation, transmission, distribution and consumption. For this purpose, different energy 
efficiency technologies are available, including electric vehicles, combined heat and power, virtual power plants and smart grids. Each of these technologies were discussed in detailed and their performances compared.

Electric vehicles have the potential to be used for both power generation and storage. Given the fact that transportation is a main contributor to the problem of emissions, improving fuel efficiency with the adoption of electric vehicle technology on a large scale will enable greater energy savings and $\mathrm{CO}_{2}$ reductions. Advances in smart grid technology impact the large scale use of electric vehicles and enhance the efficiency of the technology. However, managing load and supply fluctuations is a challenge. Combined heat and power technologies provide substantial gains in efficiency. The technology offers an efficiency use of fuel by preventing the discarding energy as waste heat. A significant part of waste heat can be transformed into a product for heating buildings, adding to its economic value and improving energy efficiency. A virtual power plant is a cluster of distributed energy resources controlled and managed by a central control unit, allowing for the possibility to control home appliances to optimize load reductions. It helps to combat the energy waste problem due to distance and transmission losses.

The driving force for using renewable energy technologies are energy security, economic impacts, and $\mathrm{CO}_{2}$ emission reduction. The level of insecurity is reflected by the risk of supply disruption and the estimated costs of security itself. The emphases for the economic impacts are job creation, industrial innovation and balance of payment. Renewable energy technologies could enable countries with good solar or wind resources to implement these energy sources to meet their own domestic demand. Moreover, the cost of importing fuels can affect economic growth. If these countries could reduce their balance of payment by producing their own renewable energy to replace their dependence on fossil fuels, they could expand their capacity for investment in other sectors. Renewable energy technologies could reduce carbon dioxide emissions by replacing fossil fuels in the power generation industry and transportation sector. Life-cycle $\mathrm{CO}_{2}$ emissions for renewable energy technologies are much lower than fossil fuels.

This review of renewable energy generation and efficiency technologies has provided detailed and useful information that can be used in the decision making of different stakeholders in the rapidly developing market. Each technology has both advantages and disadvantages that vary by location, availability, the technological capability of producers, financial limitations and environmental considerations. Each municipality, region or country has different initial conditions that determine the energy mix that can be produced at the lowest cost while minimizing the harm done to the environment. Thus, there is no single solution to every energy need and problem, but rather an optimal location specific solution among a set of possible renewable solutions.

\section{References}

Andersen, P.H., Mathews, J A., \& Rask, M. (2009). Integrating private transport into renewable energy policy: The strategy of creating intelligent recharging grids for electric vehicles. Energy Policy, 37(7), 2481-2486.

Asif, M., \& Muneer, T. (2007). Energy supply, its demand and security issues for developed and emerging economies. Renewable and Sustainable Energy Reviews, 11(7), 1388-1413.

Benitez, L E., Benitez, P C., \& Van Kooten, G C. (2008). The economics of wind power with energy storage. Energy Economics, 30(4), 1973-1989.

Bhattacharyya, S. C. (2011). Energy Economics: Concepts, Issues, Markets and Governance: 
Springer.

Blanco, M I. (2009). The economics of wind energy. Renewable and Sustainable Energy Reviews, 13(6), 1372-1382.

Bodansky, D. (2005). Costs of Electricity. Nuclear Energy: Principles, Practices, and Prospects, 559-577.

BP. (2012). BP Statistical Review of World Energy.

Branker, K., Pathak, M., \& Pearce, J. (2011). A review of solar photovoltaic levelized cost of electricity. Renewable and Sustainable Energy Reviews, 15(9), 4470-4482.

Chamorro, C R., Mondéjar, M E., Ramos, R., Segovia, J J., Martín, M C., \& Villamañán, M A. (2012). World geothermal power production status: Energy, environmental and economic study of high enthalpy technologies. Energy, 42(1), 10-18.

Christidis, A., Koch, C., Pottel, L., \& Tsatsaronis, G. (2012). The contribution of heat storage to the profitable operation of combined heat and power plants in liberalized electricity markets. Energy, 41(1), 75-82.

Connolly, D., Lund, H., Finn, P., Mathiesen, B V., \& Leahy, M. (2011). Practical operation strategies for pumped hydroelectric energy storage (PHES) utilising electricity price arbitrage. Energy Policy, 39(7), 4189-4196.

Crawford, R. (2009). Life cycle energy and greenhouse emissions analysis of wind turbines and the effect of size on energy yield. Renewable and Sustainable Energy Reviews, 13(9), 2653-2660.

Deane, J P., Ó Gallachóir, B., \& McKeogh, E. (2010). Techno-economic review of existing and new pumped hydro energy storage plant. Renewable and Sustainable Energy Reviews, 14(4), 1293-1302.

Depuru, S.S.S.R., Wang, L., \& Devabhaktuni, V. (2011). Smart meters for power grid: Challenges, issues, advantages and status. Renewable and Sustainable Energy Reviews, 15(6), 2736-2742.

Devine Jr, W. (1977). Energy analysis of a wind energy conversion system for fuel displacement: Institute for Energy Analysis, Oak Ridge, TN (USA).

Edenhofer, O., Knopf, B., Barker, T., Baumstark, L., Bellevrat, E., Chateau, B., . . . Kypreos, S. (2010). The economics of low stabilization: model comparison of mitigation strategies and costs. The Energy Journal, 31(1), 11-48.

Ehnberg, S., \& Bollen, M.H. (2005). Reliability of a small power system using solar power and hydro. Electric Power Systems Research, 74(1), 119-127.

Faruqui, A., Harris, D., \& Hledik, R. (2010). Unlocking the€ 53 billion savings from smart meters in the EU: How increasing the adoption of dynamic tariffs could make or break the EU's smart grid investment. Energy Policy, 38(10), 6222-6231.

Faruqui, A., Hledik, R., Newell, S., \& Pfeifenberger, H. (2007). The power of 5\%. The Electricity Journal, 20(8), 68-77.

Feltrin, A., \& Freundlich, A. (2008). Material considerations for terawatt level deployment of photovoltaics. Renewable Energy, 33(2), 180-185.

Ford, A. (1995). The impacts of large scale use of electric vehicles in southern California. Energy and Buildings, 22(3), 207-218.

Frankl, P., Masini, A., Gamberale, M., \& Toccaceli, D. (1997). Simplified life-cycle analysis of PV systems in buildings: present situation and future trends: INSEAD, Centre for the Management of Environmental Resources.

Frick, S., Kaltschmitt, M., \& Schröder, G. (2010). Life cycle assessment of geothermal binary power plants using enhanced low-temperature reservoirs. Energy, 35(5), 2281-2294.

Fridleifsson, I.B., \& Freeston, D.H. (1994). Geothermal energy research and development. Geothermics, 23(2), 175-214. 
Frondel, M., Ritter, N., Schmidt, C. M., \& Vance, C. (2010). Economic impacts from the promotion of renewable energy technologies: The German experience. Energy Policy, 38(8), 4048-4056.

Fthenakis, V., Mason, J.E., \& Zweibel, K. (2009). The technical, geographical, and economic feasibility for solar energy to supply the energy needs of the US. Energy Policy, 37(2), 387-399.

Fthenakis, V.M., \& Kim, H.C. (2007). Greenhouse-gas emissions from solar electric-and nuclear power: A life-cycle study. Energy Policy, 35(4), 2549-2557.

Fthenakis, V.M., Kim, H.C., \& Alsema, E. (2008). Emissions from photovoltaic life cycles. Environmental science \& technology, 42(6), 2168-2174.

Gagnon, L., \& van de Vate, J.F. (1997). Greenhouse gas emissions from hydropower: the state of research in 1996. Energy Policy, 25(1), 7-13.

Gevorkian, P. (2012). Large Scale Solar Power Systems: Construction and Economics: Cambridge University Press.

Gipe, P. (1995). Wind energy comes of age (Vol. 4): Wiley.

Gordon, J. (1987). Optimal sizing of stand-alone photovoltaic solar power systems. Solar Cells, 20(4), 295-313.

Haack, B.N. (1981). Net energy analysis of small wind energy conversion systems. Applied energy, 9(3), 193-200.

Hartway, R., Price, S., \& Woo, C. (1999). Smart meter, customer choice and profitable timeof-use rate option. Energy, 24(10), 895-903.

Hawkes, A., \& Leach, M. (2007). Cost-effective operating strategy for residential microcombined heat and power. Energy, 32(5), 711-723.

Heshmati A. (2014), "Demand, Customer Base-Line and Demand Response in the Electricity Market: A Survey”, Journal of Economics Surveys 28(3).

Huo, M., Zhang, X., \& He, J. (2011). Causality relationship between the photovoltaic market and its manufacturing in China, Germany, the US, and Japan. Frontiers in Energy, 5(1), 43-48.

IEA. (2012a). Energy Technology Perspectives 2012: OECD Publishing.

IEA. (2012b). Medium-Term Renewable Energy Market Report 2012: OECD Publishing.

IEA. (2012c). World Energy Outlook 2012: OECD Publishing.

Ito, M., Kato, K., Komoto, K., Kichimi, T., \& Kurokawa, K. (2008). A comparative study on cost and life-cycle analysis for 100 MW very large-scale PV (VLS-PV) systems in deserts using m-Si, a-Si, CdTe, and CIS modules. Progress in Photovoltaics: Research and Applications, 16(1), 17-30.

Jacobsson, S., \& Bergek, A. (2004). Transforming the energy sector: the evolution of technological systems in renewable energy technology. Industrial and corporate change, 13(5), 815-849.

Jäger-Waldau, A. (2006). European Photovoltaics in world wide comparison. Journal of noncrystalline solids, 352(9), 1922-1927.

Jansen, B., Binding, C., Sundstrom, O., \& Gantenbein, D. (2010). Architecture and communication of an electric vehicle virtual power plant. Paper presented at the Smart Grid Communications (SmartGridComm), 2010 First IEEE International Conference on.

Kaldellis, J., Kapsali, M., \& Kavadias, K. (2010). Energy balance analysis of wind-based pumped hydro storage systems in remote island electrical networks. Applied energy, 87(8), 2427-2437.

Kapsali, M., \& Kaldellis, J. (2010). Combining hydro and variable wind power generation by means of pumped-storage under economically viable terms. Applied energy, 87(11), 3475-3485. 
Karnouskos, S., Terzidis, O., \& Karnouskos, P. (2007). An advanced metering infrastructure for future energy networks New Technologies, Mobility and Security (pp. 597-606): Springer.

Kaya, E., Zarrouk, S.J., \& O'Sullivan, M.J. (2011). Reinjection in geothermal fields: A review of worldwide experience. Renewable and Sustainable Energy Reviews, 15(1), 47-68.

Kempton, W., \& Letendre, S.E. (1997). Electric vehicles as a new power source for electric utilities. Transportation Research Part D: Transport and Environment, 2(3), 157-175.

Kempton, W., \& Tomić, J. (2005). Vehicle-to-grid power implementation: From stabilizing the grid to supporting large-scale renewable energy. Journal of Power Sources, 144(1), 280-294.

Kieny, C., Berseneff, B., Hadjsaid, N., Besanger, Y., \& Maire, J. (2009). On the concept and the interest of Virtual Power plant: some results from the European project FENIX. Paper presented at the Power \& Energy Society General Meeting, 2009. PES'09. IEEE.

Kiviluoma, J., \& Meibom, P. (2010). Influence of wind power, plug-in electric vehicles, and heat storages on power system investments. Energy, 35(3), 1244-1255.

Klaassen, G., Miketa, A., Larsen, K., \& Sundqvist, T. (2005). The impact of R\&D on innovation for wind energy in Denmark, Germany and the United Kingdom. Ecological Economics, 54(2), 227-240.

Kolhe, M., Kolhe, S., \& Joshi, J. (2002). Economic viability of stand-alone solar photovoltaic system in comparison with diesel-powered system for India. Energy Economics, 24(2), 155-165.

Korpaas, M., Holen, A.T., \& Hildrum, R. (2003). Operation and sizing of energy storage for wind power plants in a market system. International Journal of Electrical Power \& Energy Systems, 25(8), 599-606.

Krishnamurti, T., Schwartz, D., Davis, A., Fischhoff, B., de Bruin, W.B., Lave, L., \& Wang, J. (2012). Preparing for smart grid technologies: A behavioral decision research approach to understanding consumer expectations about smart meters. Energy Policy, 41, 790-797.

Kubiszewski, I., Cleveland, C.J., \& Endres, P.K. (2010). Meta-analysis of net energy return for wind power systems. Renewable Energy, 35(1), 218-225.

Lehner, B., Czisch, G., \& Vassolo, S. (2005). The impact of global change on the hydropower potential of Europe: a model-based analysis. Energy Policy, 33(7), 839-855.

Lenzen, M., \& Munksgaard, J. (2002). Energy and CO2life-cycle analyses of wind turbinesreview and applications. Renewable Energy, 26(3), 339-362.

Lenzen, M., \& Wachsmann, U. (2004). Wind turbines in Brazil and Germany: an example of geographical variability in life-cycle assessment. Applied energy, 77(2), 119-130.

Liberman, E.J. (2003). A life cycle assessment and economic analysis of wind turbines using Monte Carlo simulation: DTIC Document.

Lin, G.T. (2011). The Promotion and Development of Solar Photovoltaic Industry: Discussion of Its Key Factors. Distributed Generation \& Alternative Energy Journal, 26(4), 57-80.

Lund, H., \& Kempton, W. (2008). Integration of renewable energy into the transport and electricity sectors through V2G. Energy Policy, 36(9), 3578-3587.

Lund, J.W., Freeston, D.H., \& Boyd, T.L. (2005). Direct application of geothermal energy: 2005 worldwide review. Geothermics, 34(6), 691-727.

Maidment, G., \& Tozer, R. (2002). Combined cooling heat and power in supermarkets. Applied thermal engineering, 22(6), 653-665.

Martinot, E., \& Sawin, J. (2012). Renewables global status report: 2012 update.

McHenry, M.P. (2013). Technical and governance considerations for advanced metering infrastructure/smart meters: Technology, security, uncertainty, costs, benefits, and risks. 
Energy Policy.

McKenna, E., Richardson, I., \& Thomson, M. (2012). Smart meter data: Balancing consumer privacy concerns with legitimate applications. Energy Policy, 41, 807-814.

Monteiro, C., Ramirez-Rosado, I.J., \& Fernandez-Jimenez, L.A. (2013). Short-term forecasting model for electric power production of small-hydro power plants. Renewable Energy, 50, 387-394.

Murphy, H., \& Niitsuma, H. (1999). Strategies for compensating for higher costs of geothermal electricity with environmental benefits. Geothermics, 28(6), 693-711.

Nawaz, I., \& Tiwari, G. (2006). Embodied energy analysis of photovoltaic (PV) system based on macro-and micro-level. Energy Policy, 34(17), 3144-3152.

Ngô, C., \& Natowitz, J. (2009). Our energy future: resources, alternatives and the environment (Vol. 11): Wiley.

Nieuwenhout, F., Van Dijk, A., Lasschuit, P., Van Roekel, G., Van Dijk, V., Hirsch, D., ... . Wade, H. (2001). Experience with solar home systems in developing countries: a review. Progress in Photovoltaics: Research and Applications, 9(6), 455-474.

OECD. (2010). Projected Costs of Generating Electricity 2010: OECD Publishing.

Oliver, M., \& Jackson, T. (1999). The market for solar photovoltaics. Energy Policy, 27(7), 371-385.

Ölz, S. (2011). Renewable Energy Policy Considerations for Deploying Renewables.

Owen, A. D. (2004). Oil supply insecurity: control versus damage costs. Energy Policy, 32(16), 1879-1882.

Paish, O. (2002). Small hydro power: technology and current status. Renewable and Sustainable Energy Reviews, 6(6), 537-556.

Pudjianto, D., Ramsay, C., \& Strbac, G. (2007). Virtual power plant and system integration of distributed energy resources. Renewable power generation, IET, 1(1), 10-16.

Purkus, A., \& Barth, V. (2011). Geothermal power production in future electricity marketsA scenario analysis for Germany. Energy Policy, 39(1), 349-357.

Raadal, H.L., Gagnon, L., Modahl, I.S., \& Hanssen, O.J. (2011). Life cycle greenhouse gas (GHG) emissions from the generation of wind and hydro power. Renewable and Sustainable Energy Reviews, 15(7), 3417-3422.

Ragwitz, M., Schade, W., Breitschopf, B., Walz, R., Helfrich, N., Rathmann, M., . . Haas, R. (2009). The impact of renewable energy policy on economic growth and employment in the European Union. Brussels, Belgium: European Commission, DG Energy and Transport.

Raugei, M., \& Frankl, P. (2009). Life cycle impacts and costs of photovoltaic systems: Current state of the art and future outlooks. Energy, 34(3), 392-399.

Ruiz, N., Cobelo, I., \& Oyarzabal, J. (2009). A direct load control model for virtual power plant management. Power Systems, IEEE Transactions on, 24(2), 959-966.

Saner, D., Juraske, R., Kübert, M., Blum, P., Hellweg, S., \& Bayer, P. (2010). Is it only CO< sub $>2</$ sub $>$ that matters? A life cycle perspective on shallow geothermal systems. Renewable and Sustainable Energy Reviews, 14(7), 1798-1813.

Sarver, T., Al-Qaraghuli, A., \& Kazmerski, L.L. (2013). A comprehensive review of the impact of dust on the use of solar energy: History, investigations, results, literature, and mitigation approaches. Renewable and Sustainable Energy Reviews, 22, 698-733.

Schleisner, L. (2000). Life cycle assessment of a wind farm and related externalities. Renewable Energy, 20(3), 279-288.

Schulz, C., Roder, G., \& Kurrat, M. (2005). Virtual Power Plants with combined heat and power micro-units. Paper presented at the Future Power Systems, 2005 International Conference on. 
Shipley, M.A., Hampson, A., Hedman, M.B., Garland, P.W., \& Bautista, P. (2008). Combined heat and power: Effective energy solutions for a sustainable future: Oak Ridge National Laboratory (ORNL).

Shum, K.L., \& Watanabe, C. (2007). Photovoltaic deployment strategy in Japan and the USA —an institutional appraisal. Energy Policy, 35(2), 1186-1195.

Sinha, A. (1993). Modelling the economics of combined wind/hydro/diesel power systems. Energy conversion and management, 34(7), 577-585.

Steenhof, P.A., \& McInnis, B.C. (2008). A comparison of alternative technologies to decarbonize Canada's passenger transportation sector. Technological Forecasting and Social Change, 75(8), 1260-1278.

Stefansson, V. (2002). Investment cost for geothermal power plants. Geothermics, 31(2), 263272.

Sundararagavan, S., \& Baker, E. (2012). Evaluating energy storage technologies for wind power integration. Solar Energy.

Ten Hoeve, J. E., \& Jacobson, M. Z. (2012). Worldwide health effects of the Fukushima Daiichi nuclear accident. Energy \& Environmental Science, 5(9), 8743-8757.

Tester, J.W. (2005). Sustainable energy: choosing among options: The MIT Press.

Tomić, J., \& Kempton, W. (2007). Using fleets of electric-drive vehicles for grid support. Journal of Power Sources, 168(2), 459-468.

Tremeac, B., \& Meunier, F. (2009). Life cycle analysis of 4.5 MW and 250W wind turbines. Renewable and Sustainable Energy Reviews, 13(8), 2104-2110.

Tsoutsos, T., Frantzeskaki, N., \& Gekas, V. (2005). Environmental impacts from the solar energy technologies. Energy Policy, 33(3), 289-296.

Vojdani, A. (2008). Smart integration. Power and Energy Magazine, IEEE, 6(6), 71-79.

Wagner, H.-J., \& Pick, E. (2004). Energy yield ratio and cumulative energy demand for wind energy converters. Energy, 29(12), 2289-2295.

Weiller, C. (2011). Plug-in hybrid electric vehicle impacts on hourly electricity demand in the United States. Energy Policy, 39(6), 3766-3778.

Wille-Haussmann, B., Erge, T., \& Wittwer, C. (2010). Decentralised optimisation of cogeneration in virtual power plants. Solar Energy, 84(4), 604-611.

Wirl, F. (1989). Optimal capacity expansion of hydro power plants. Energy Economics, 11(2), 133-136.

Yang, C.-J.,\& Jackson, R.B. (2011). Opportunities and barriers to pumped-hydro energy storage in the United States. Renewable and Sustainable Energy Reviews, 15(1), 839-844.

You, S., Træholt, C., \& Poulsen, B. (2009). A market-based virtual power plant. Paper presented at the Clean Electrical Power, 2009 International Conference on.

You, S., Traholt, C., \& Poulsen, B. (2009). A study on electricity export capability of the $\mu C H P$ system with spot price. Paper presented at the Power \& Energy Society General Meeting, 2009. PES'09. IEEE. 